\title{
Monetary Policy and Bank Risk-Taking: Evidence from the Corporate Loan Market
}

\author{
Teodora Paligorova* \\ Bank of Canada \\ E-mail: tpaligorova@bankofcanada.ca \\ João A. C. Santos* \\ Federal Reserve Bank of New York \\ and \\ Nova School of Business and Economics \\ E-mail: joao.santos@ny.frb.org
}

November 22, 2012

\begin{abstract}
Our investigation of banks' corporate loan pricing policies in the United States over the past two decades finds that monetary policy is an important driver of banks' risk-taking incentives. We show that banks charge riskier borrowers (relative to safer borrowers) lower premiums in periods of easy monetary policy than in periods of tight monetary policy. This interest rate discount is robust to borrower-, loan-, and bank-specific factors, macroeconomic factors and various types of unobserved heterogeneity at the bank and firm levels. Using individual bank information about lending standards from the Senior Loan Officers Opinion Survey (SLOOS), we unveil evidence that the interest rate discount for riskier borrowers in periods of easy monetary policy is prevalent among banks with greater risk appetite. This finding confirms that the loan pricing discount we observe is indeed driven by the bank risk-taking channel of monetary policy.
\end{abstract}

JEL classification: G21

Key words: Monetary policy, risk-taking channel, loan spreads

\footnotetext{
*The authors thank Jose Berrospide, Christa Bouwman, Daniel Carvalho, Scott Hendry, Kim Huynh, David Martinez-Miera and seminar participants at Nova School of Business and Economics, SFU Beedie School of Business, the 2012 FIRS Meeting in Minneapolis, and the 2012 Bank of Spain and Bank of Canada "International Financial Markets" Workshop for useful comments. We thank Vitaly Bord for outstanding research assistance. The views stated herein are those of the authors and are not necessarily the views of the Bank of Canada, the Federal Reserve Bank of New York or the Federal Reserve System.
} 


\section{Introduction}

There has been a great deal of interest in exploring banks' risk-taking incentives because of their important role in the stability of the financial system. Researchers have unveiled evidence linking banks' appetite for risk to their ownership structures (Saunders et al. (1990)), competition in the banking sector (Keeley (1990)), the presence of deposit insurance (Hovakimian and Kane (2000)), government bailout policies (Gropp et al. (2011)), and the compensation of bank managers (DeYoung et al. (2012)). More recently, researchers have focused on monetary policy as yet another potential driver of banks' incentives to take on risk. In this paper, we attempt to contribute to the ongoing debate on the effects of monetary policy on banks' risk-taking incentives by investigating whether U.S. monetary policy over the past two decades led banks to underprice risk when extending loans to corporations.

The potential effects of monetary policy on banks' risk-taking incentives have received wide attention in the wake of the latest financial crisis, following claims that the accommodative policies of the Federal Reserve spurred risk-taking among financial intermediaries. ${ }^{1}$ Low interest rates can lead banks to take on more risk for a number of reasons. They may cause banks to make risky investments in a "search for yield" (Rajan (2006)). Financial institutions often enter into long-term contracts that commit them to producing high nominal rates of return. In periods of low interest rates, these contractual rates may exceed the yields available on safe assets. To earn excess returns, banks may turn to risky assets. ${ }^{2}$

The effect of low interest rates on valuations may also affect bank risk-taking. As asset and collateral values increase, banks' perception of risk - including their risk estimates - may decline, leading to more risk-taking. In addition, volatility tends to decrease when prices go up and this effect may release risk budgets, permitting financial institutions to take additional risks. ${ }^{3}$ Low interest rates may lead to more bank risk-taking for yet other reasons. Dell' Ariccia and Marquez (2009) point out that if low interest rates reduce adverse selection in credit markets they will decrease banks' incentive to screen loan applicants. Akerlof and Shiller (2009), on the other hand, suggest that investors take higher risks to increase returns in periods of low interest rates due to money illusion.

Until recently, the macro literature has typically focused on the link between the stance

\footnotetext{
${ }^{1}$ See Borio and Zhu (2008), Brunnermeier (2009), and Diamond and Rajan (2009).

${ }^{2}$ Similar mechanisms may come into play if managers' pay is benchmarked to targets set in times of high interest rates or if investors withdraw funds after using short-term returns to judge managers' competence (Shleifer and Vishny (1997)).

${ }^{3}$ According to Adrian and Shin (2009) low short-term rates may lead to more risk-taking because they improve banks' profitability and relax their budgetary constraints. When short-term rates and term spreads are negatively related, continued low short-term rates imply a high net interest margin for some time, which results in an increase in the risk-taking capacity of the banking sector.
} 
of monetary policy and the availability of bank credit and has not developed models that incorporate banks' risk-taking incentives. The banking literature has investigated banks' risktaking incentives, but has not considered the effects of monetary policy.

In contrast to the theoretical literature, several empirical studies have already examined the link between monetary policy and banks' risk-taking incentives. Altunbas et al. (2010) find evidence of a link between protracted periods of low interest rates and bank risk-taking, as captured by banks' expected default frequencies based on data for European- and U.S.-listed banks. Jimenez et al. (2007) document that low interest rates led Spanish banks to lend more to borrowers with bad credit histories. Ioannidou et al. (2009) document that Bolivian banks increased the number of risky loans and reduced the rates they charged risky borrowers relative to the rates for less risky ones when the Bolivian peso was pegged to the U.S. dollar and the short-term rates were low in the U.S. Finally, using information from bank lending surveys of the Euro Area and the U.S., Peydro and Maddaloni (2011) document that banks soften their lending standards in periods of low short-term rates.

In this paper, we consider a novel approach to investigating the effects of monetary policy on banks' risk-taking incentives. We focus on banks' loan pricing policies and investigate whether banks offer an interest rate discount to riskier borrowers in periods of low versus periods of high short-term interest rates. ${ }^{4}$ The results of this part of our investigation show that banks decrease the loan spread difference between riskier and safer borrowers in periods of low versus high interest rates after controlling for a large set of borrower-, loan- and bankspecific factors as well as a set of macroeconomic factors known to affect loan rates. We find that in periods of high short-term rates the average percentage difference between the loan spreads for below-investment grade borrowers and investment-grade borrowers is 117 percent. However, in periods of low short-term rates this difference shrinks significantly to only 87 percent.

The interest rate discount that banks "offer" below investment grade borrowers may derive from the increase in banks' risk appetite that occurs when short-term rates are low. It may also derive, for example, from a differential impact of short-term rates on borrowers' risk, which is not captured in borrowers' credit ratings. To address this concern, we re-estimate our test with a focus on the borrower's probability of default. Since this is a market-based (and thus forward-looking) measure of risk, it should account for any effect that short-term rates may have on the borrower's risk of default. We continue to find that when short-term rates are low, the loan spreads for riskier borrowers are relatively lower than those for safer ones. On average, a one percent increase in the probability of default leads to a 188 percent increase

\footnotetext{
${ }^{4}$ We use the terms "low interest rates," "loose monetary policy," and "easy monetary policy" interchangeably. The same applies for "high interest rates" and "tight monetary policy."
} 
in loan spreads in the period when interest rates are high, but only to a 148 percent spread differential when short-term interest rates are low.

While this finding is consistent with the evidence that monetary policy affects banks' risk-taking incentives, it may also derive from other factors not directly related to bank risktaking. For example, it may only be the effect of the balance sheet channel. ${ }^{5}$ To the extent that our firm controls account for the firm's demand for credit over time, including them should reduce concerns related to the effect of credit demand.

Further, to account for unobservable changes in loan demand we include time-firm and time-firm-bank fixed effects in the loan regressions (Khwaja and Mian (2008)). In this case, the identification comes either from comparing loan spreads for the same firm in the same time period across different banks (time-firm) or at the same bank (time-firm-bank). This approach removes the effects of different sources of unobserved heterogeneity at the credit demand level that are not related to the bank risk-taking channel of monetary policy. In addition, we study loan quantities to identify whether the lower pricing of risky loans that occurs when monetary policy is easy results from supply or demand shifts. Lower prices and lower amounts would suggest loan demand shifts while lower prices and higher quantities would more likely result from supply shifts that drive the bank risk-taking channel. We find that risky borrowers enjoy relatively larger loans than safer borrowers in easy monetary policy regimes after controlling for firm, loan, bank and macroeconomic characteristics.

Another potential concern with our findings is the expected overlap between economic cycles and monetary policy cycles. To the extent that these cycles overlap, economic conditions alone may explain our results. ${ }^{6}$ To address this possibility, we examine the interactive effects of monetary policy and the probability of default, and of economic growth and the probability of default on loan spreads. We find that riskier borrowers still pay relatively lower spreads when interest rates are as low as compared to when rates are high. Since loans originated in lowinterest-rate regimes are present in different phases of the economic cycle, we can identify the separate effects of monetary policy and economic regimes on loan spreads. In addition, we find that the interest rate discount that riskier borrowers enjoy continues to hold when we employ an alternative measure of easing monetary policy. Specifically, instead of using the actual

\footnotetext{
${ }^{5}$ This channel refers to the role of firms and banks' balance sheets or their financial positions in the transmission mechanism of monetary policy. It arises because policy shifts affect bank balance sheets, cash follows and the net worth of companies and consumers. Interest rate cuts result in higher cash flows, higher net worth, increases in the amount of loans, and ultimately an increase in aggregate demand. See Bernanke (1983), Bernanke and Blinder (1992), Bernanke and Gertler (1995), Kashyap and Stein (2000) and Oliner and Rudebisch (1996) for an extensive discussion.

${ }^{6}$ Erel et al. (2012) show that macroeconomic conditions play an important role in firms' decisions to raise debt financing. They find that borrowers rated below investment grade raise less debt when market conditions are poor, while investment-grade-rated borrowers issue more debt.
} 
federal funds rate, we identify easing based on monetary policy shocks as suggested by Romer and Romer (2004). The advantage of this approach is that it accounts for the endogeneity between monetary policy and economic conditions, and policymakers' beliefs about the future path of the economy.

Notwithstanding these findings, one may still wonder if this discount arises from changes in banks' risk-taking incentives in those periods. For instance, banks (similarly to firms) may experience an improvements in their balance sheets, may in turn increase their lending activity. If risky firms also experience a relative increase in net worth and hence demand more credit, banks may lend to them, which is consistent with observing an interest rate discount and interpreting it as evidence of the risk-taking channel of monetary policy. This, however, is only the joint outcome of changes in banks' credit supply and firms' credit demand.

Our time-varying bank balance sheet controls should account for some of these supply effects. Further, our use of bank-fixed effects will account for unobservable supply effects on loan interest rates. This approach addresses time-invariant bank factors, but it does not account for unobservable changes in the pool of borrowers across different monetary policy regimes. For this reason, we show that our finding continues to hold when we control for bankfirm fixed effects by comparing loan spreads for the same borrower and bank under different economic and monetary conditions. To the extent that credit supply and demand are driven by endogenous matching between lenders and borrowers, including bank-firm fixed effects should account for it.

To reduce concerns that our findings are unrelated to bank policies, but instead are the result of omitted economic factor(s), we investigate the effect of monetary policy on bond spreads (over Treasuries) in the primary market. Unlike banks, bond investors are not protected by the safety net and hence are unlikely to take as much risk as banks when monetary policy is loose. Using an approach similar to the one we used to investigate banks' loan pricing policies, we do not find that riskier firms enjoy a discount compared to safer firms when they issue bonds in periods of low interest rates. It appears, therefore, that the risk appetite of bond investors - usually insurance companies, pension funds and other investment managers - is not affected by the stance of the monetary policy in the same way as the risk appetite of banks.

Having ruled out several potential explanations for the interest rate discount provided to riskier borrowers in periods of low short-term interest rates, one may still wonder if it arises from a change in banks' risk appetite. To provide assurance that it does, we design several tests using bank-level information from the Senior Loan Officers Opinion Survey (SLOOS). This survey is critical to identifying the effects of the monetary policy on banks' risk-taking incentives because it reports key information about banks' lending standards and risk tolerance. ${ }^{7}$

${ }^{7}$ Peydro and Maddaloni (2011) also consider information in the SLOOS. However, in contrast to us, they 
In one of the tests, we use banks' responses to the SLOOS question asking whether "increased tolerance for risk" played an important role in their decisions to ease lending standards. This information allows us to confirm whether the interest rate discount that risky borrowers enjoy when monetary policy is easying versus tightening is indeed coming from banks with greater risk appetite - and hence whether it is associated with the risk-taking channel of monetary policy. The results show that banks with greater risk tolerance offer an interest rate discount to riskier borrowers. The spread between risky and safe borrowers across more risk-tolerant banks is smaller than the spread across less risk-tolerant banks - but only when interest rates are low. This finding confirms that the interest rate discount that risky borrowers enjoy when short-term rates are low is indeed driven by an increase in banks' risk appetite.

In sum, our paper provides strong evidence that monetary policy affects banks' risk taking incentives. As a result, risky borrowers benefit from an interest rate discount (relative to safe borrowers) when they borrow from banks in periods of easy monetary policy. Our paper adds to the recent studies on bank risk-taking and monetary policy in many important respects. In contrast to these studies, our paper focuses on the U.S., where the debate on banks' increased appetite for risk originated in 2007. We also attempt to identify bank risktaking incentives by investigating banks' loan policies. This part of our paper is related to Ioannidou et al. (2009), but it differs in many important respects. For instance, they focus on banks' risk-taking incentives in Bolivia while we investigate banks' loan pricing policies in the U.S. ${ }^{8}$ We control for loan-, bank- and borrower-specific characteristics. They too control for loan- and bank-specific characteristics, but for confidentiality reasons are unable to control for borrower-specific characteristics. Since borrowers may be both balance-sheet constrained and bank-dependent (Gertler and Gilchrist (1994)), any analysis based either on firm-level or on bank-level data suffers from an omitted-variable problem. For that reason, it is important to use individual loan-level information together with bank and firm characteristics.

Finally, we provide new evidence that banks' loan-pricing policies are indeed driven by the differential impact of banks' risk appetite when monetary policy is easy versus when it is tight. We do not find that risky borrowers in our sample enjoy an interest rate discount (relative to safe borrowers) when they raise funding in the bond market in periods of low shortterm rates. In addition, building on the information about banks' lending standards from the SLOOS, we are able to confirm that the interest rate discount that risky borrowers enjoy in periods of low short-term interest rates is the result of changes in banks' risk appetite.

rely on the aggregated information from the publicly available SLOOS, and use this information to examine whether banks adopt softer lending standards when interest rates remain low for a prolonged period.

${ }^{8}$ Their key measure of loan risk is the probability of default in the current period, conditional on survival until that period. We focus instead on the market-based - and thus forward-looking - probability of borrower default. 
The remainder of our paper is organized as follows. We discuss the data, empirical strategy and sample characteristics in section 2 . In section 3, we examine the impact of the monetary policy regime on loan spreads. In section 4 we provide several test of the effect of loan demand. Section 5 reports the results of bond spread regressions. In section 5 , we report several robustness tests; in section 6 we report results from bond spreads. Section 7 presents the results of tests that build on the SLOOS data. Section 8 concludes the paper.

\section{Data, methodology, and sample characterization}

\subsection{Data}

The data for this project come from several sources, including the Loan Pricing Corporation's Dealscan database (LPC), the stock price data of the Center for Research on Securities Prices (CRSP), Merrill Lynch's bond yield indices, Compustat, the Federal Reserve's Bank Call Reports, fixed investment securities database (FISD), and the Federal Reserve's Senior Loan Officer Opinion Survey on bank lending practices.

We use LPC's Dealscan database of business loans to identify the firms that borrowed from banks and when they did so. Most of the loans in this database are syndicated. The database goes as far back as the beginning of the 1980s. In the first part of that decade, the database had a somewhat reduced number of entries, but its comprehensiveness has increased steadily over time. It is for this reason that we begin our sample in 1990. Our sample ends in 2010. We also use the Dealscan database to obtain information on individual loans, including the loan's spread over LIBOR (that is, the London interbank offering rate), maturity, seniority status, purpose and type; information about the borrower, including its sector of activity, and its legal status (private or public firm); and finally, information on the lending syndicate, including the identity and role of the banks in the loan syndicate.

We use Compustat to get information on firms' balance sheets. Even though LPC contains loans from both privately held firms and publicly listed firms, given that Compustat is dominated by publicly held firms, we have to exclude loans to privately held firms from our sample.

We rely on the CRSP database to link companies and subsidiaries that are part of the same firm and to link companies over time that went through mergers, acquisitions or name changes. ${ }^{9}$ We then use these links to merge the LPC and Compustat databases to find out the financial condition of the firm at the time it borrowed from banks. We also use CRSP to gather data on firms' stock prices.

\footnotetext{
${ }^{9}$ We adopted a conservative criterion and dropped companies that could not be reasonably linked.
} 
We use Merrill Lynch's yield indexes on new long-term industrial bonds to control for changes in the risk premium in the credit markets. We consider the indexes on yields of triple- $\mathrm{A}$ and triple-B rated bonds because these go further back in time than the indexes on the investment-grade and below-grade bonds.

We rely on the Reports of Condition and Income compiled by the Federal Deposit Insurance Corporation, the Comptroller of the Currency, and the Federal Reserve System to obtain bank data, including capital-to-asset ratio, size, profitability and risk, for the lead bank(s) in each loan syndicate. Wherever possible, we get these data at the bank holding company level using Y9C reports. When these reports are not available, we rely on Call Reports, which have data at the bank level.

We use the Fed's SLOOS to get information on the lead bank's lending policy. Since the late 1960s, the Fed has collected quarterly information on loan officers judgments about changes of non-price lending practices. ${ }^{10}$ The survey collects information through multipleor dichotomous-choice questions, that is, respondents must select a response from a provided list. Over the years the survey sample as well as its format has been adjusted several times. In the early years the survey covered at least 121 banks and the Fed conducted the survey through written questionnaires. In May 1981, the sample was cut to 60 large U.S. commercial banks, and the Fed began conducting the survey through telephone interviews with senior loan officers. Over the years, the Fed has added questions to capture the various aspects of banks' lending policies that became relevant, including questions about mortgage lending and consumer loans. However, the part of the survey that is of interest to us as well as the set of banks surveyed remained unchanged during our sample period.

We consider the answers the banks provide to the following three questions of the survey. The first question asks whether the bank's credit standards for approving applications for commercial and industrial (C\&I) loans were, on net, tighter, easier, or unchanged from three months earlier. The second question asks the bank about the importance of "increased (reduced) tolerance for risk" when it eases (tightens) the terms for C\&I loans. Finally, we consider the answers banks provide to the question that asks whether the demand for C\&I loans weakened or strengthened (apart from normal seasonal variation) over the past three months.

Finally, to conduct an analysis of the effect of monetary policy on the spreads that borrowers in our sample pay to raise bond financing, we use SDC's Domestic New Bond Issuances database. Bond spread is the credit spread at issuance over the Treasury with the same maturity. We also use information about issuance amount, maturity, whether the bond is callable, convertible, and it has a variable coupon.

\footnotetext{
${ }^{10}$ For further details on the Survey of Senior Loan Officers Opinion, see Schreft and Owens (1991).
} 


\subsection{Methodology}

Our methodology has two parts. The first part investigates whether banks' risk-taking incentives vary with the stance of monetary policy and in particular whether their risk appetite is higher when interest rates are low. To that end, we compare the difference in the loan spreads for risky and safe borrowers when interest rates are low with the same spread difference when interest rates are high, controlling for a set of factors known to explain loan spreads.

Even though the first part of our methodology controls for a large set of bank factors and focuses on within-bank results, the question may still arise as to whether differences in spreads indeed capture differences in banks' risk appetite. To address this concern, in the second part of our methodology we investigate the spreads (over Treasury) that firms in our sample pay to raise funding in the bond market in an attempt to explore if risky borrowers also benefit from a discount (relative to safe borrowers) in the bond market when short-term rates are low.

In addition, we design a two-step exercise using information on lending standards from SLOOS that aims at directly measuring banks' willingness to take risks. In the first step, we use bank information about lending standards form the SLOOS to isolate changes in those standards that are likely attributable to unobservable factors related to banks' risk-taking incentives. This information is then used in the second step to ascertain whether banks' willingness to take on more risk leads to commensurate changes in their loan pricing policies. We describe below in detail the procedures we follow in the two parts of our methodology.

\subsubsection{Banks' risk-taking and the monetary policy stance}

To ascertain whether banks charge relatively lower loan spreads to riskier borrowers when interest rates are low than when they are high, we investigate the following model of loan spreads:

$$
\begin{aligned}
L L O A N S P D_{f, l, b, t} & =c+\alpha L O W R A T E_{t}+\beta B O R R I S K_{f, t} \\
& +\gamma L O W R A T E_{t} \times B O R R I S K_{f, t-1} \\
& +\psi \cdot X_{i, f, t}+\nu \cdot Y_{j, f, t-1}+\eta \cdot Z_{k, b, t-1}+\zeta \cdot M_{u, t-1}+\epsilon_{f, l, b, t}
\end{aligned}
$$

$L L O A N S P D_{f, l, b, t}$ is the natural $\log$ of the all-in-drawn spread over LIBOR of loan $l$ to firm $f$ from bank $b$ at issue date $t$. According to Dealscan, our source of loan data, the all-in-drawn spread is a measure of the overall cost of the loan, expressed as a spread over LIBOR, because it takes into account both one-time and recurring fees associated with the loan.

$L O W R A T E_{t}$ is a dummy variable that is equal to one if the federal funds rate at 
the time of loan origination is below the sample median of the federal funds rate. We have experimented with other cutoff points of the federal funds rate distribution such as the 30th and 20th percentiles. Since our objective is to address the question of whether banks are more risk-taking when interest rates remain low for a prolonged period of time, we focus on the effect of the stance of monetary policy over a time period as opposed to quarterly changes in the monetary policy rate. It is for this reason that we use a dummy variable which isolates prolonged periods of relatively low from relatively high rates. Banks usually charge lower interest rates on their corporate loans when the federal funds rate is low because of the reduced cost of funding. However, the decline in interest rates may not always accompany the decline in the federal funds rate. As a result, loan spreads may be higher when short-term interest rates are low.

$B O R R I S K_{f, t-1}$ is a measure of the risk of default of the borrower computed in the quarter prior to the loan. Since banks usually charge higher spreads on loans to borrowers with a higher risk of default, we expect $\beta>0$. We consider two alternative measures of the borrower's risk of default. The first measure is the credit rating of the borrower. In this case, BOR RISK is the dummy variable $B G R A D E$, which equals 1 for borrowers rated below investment grade, and $U N R A T E D$, which equals 1 for unrated borrowers. The omitted category includes the borrowers rated investment grade. Our second measure is a proxy for the borrower's probability of default. In this case, BOR RISK is PDEFAULT, which we measure following Bharath and Shumway (2008)'s "naive" estimate of the firm's probability of default. This is a "simple" implementation of Merton (1974)'s model of corporate bankruptcy.

Our second measure of the borrower's risk of default has two advantages over the first one. Not all firms have a credit rating. In contrast, it is possible to compute our naive probability of default for all firms that are publicly listed. Credit ratings, in addition, have been extensively questioned as a forward-looking measure of firm risk. Our naive estimate of the firm's probability of default is more likely a forward-looking measure of the firm's risk of default because it is driven by market information. This feature is particularly important for us because we want to make sure that any differences in loan spreads do not come from changes in firms' risk of failure due to interest rates changes. We have computed all our tests with both measures of risk, but for the reasons we just discussed, we focus on the results that use $P D E F A U L T$ as a proxy for the borrower's risk of default.

The key variable in our model of loan spreads is the interaction between our proxy for low interest rates and our measure of the borrower's risk of default, LOW RATE $\times B O R R I S K$. If banks do indeed seek to take on more risk when short-term interest rates are low, then we should expect $\gamma<0$. In other words, banks charge risky borrowers higher spreads than safer ones, but this difference shrinks in periods of low short-term interest rates. 
As noted above, in testing this hypothesis we include a number of firm-specific controls $Y$, loan-specific controls, $X$, bank-specific controls, $Z$, and macro factors, $M$, which may also affect the spreads banks charge on their corporate loans. We begin by discussing the firmspecific variables that we use. Several of these variables are proxies for the risk of the firm. $L A G E$ is the $\log$ of the firm's age in years. To compute the firm's age, we proxy the firm's year of birth by the year of the initial public offering of its equity. Because older firms are typically better established and therefore less risky, we expect this variable to have a negative effect on the loan spread. $L S A L E S$ is the $\log$ of the firm's sales in hundreds of millions of dollars. Given that larger firms are usually better diversified across customers, suppliers, and regions, again we expect this diversification to have a negative effect on the loan spread.

We also include variables that proxy for the risk of the firm's debt rather than that of the overall business. PROF MARGIN is the firm's profit margin (net income divided by sales). LINTCOV is the firm's interest coverage, which we measure as the log of one plus the interest coverage ratio (i.e., earnings before interest, taxes, depreciation, and amortization (EBITDA) divided by interest expense). More profitable firms as well as firms with higher interest coverage have a greater cushion for servicing debt and should therefore pay lower spreads on their loans. $L E V E R A G E$ is the firm's leverage ratio (debt over total assets); higher leverage suggests a greater chance of default, which should have a positive effect on spreads.

Another aspect of credit risk is losses to debt holders in the event of default. To capture this risk, we include several variables that measure the size and quality of the asset base that debt holders can draw on in default. TANGIBLES is the firm's tangible assets - inventories plus plant, property, and equipment - as a fraction of total assets. Because tangible assets lose less of their value in default than intangible assets such as brand equity do, we expect this variable to have a negative effect on spreads. ADVERTISING is the firm's advertising expense divided by sales; because this variable proxies for the firm's brand equity, which is intangible, we expect it to have a positive effect on spreads. Similarly, $R \& D$ is the firm's research and development expense divided by sales; because this variable proxies for intellectual capital, which is intangible, we expect it to have a positive effect on spreads. ${ }^{11} N W C$ is the firm's net working capital (current assets less current liabilities) divided by total debt; given that NWC measures the liquid asset base, which is less likely to lose value in the case of default, we expect it to have a negative effect on spreads. $M K T B O O K$ is the firm's market to book ratio, which proxies for the value the firm is expected to gain by future growth. Although growth opportunities are vulnerable to financial distress, we already have controls for the

\footnotetext{
${ }^{11}$ Firms are required to report advertising expenses only when they exceed a certain value. For this reason, this variable is sometimes missing in Compustat. The same is true for expenses with research and development. In either case, when the variable is missing, we set it equal to zero.
} 
tangibility of the book value of a firm's assets. Thus, this variable could have a negative effect on spreads if it represents the additional value (over and above book value) that debt holders can partially access in the event of default.

We complement this set of firm controls with two variables linked to the firm's stock price. EX RET is the firm's excess stock return (relative to the overall market) over the past 12 months. To the extent that a firm outperforms the market's required return, it should have more cushion against default and thus a lower spread. STOCK VOL is the standard deviation of the firm's daily stock return over the past 12 months. Because higher volatility indicates greater risk, and thus a higher probability of default, we expect this variable to have a positive impact on spreads. Since EX RET, STOCK VOL, and LEVERAGE are the key components of Bharath and Shumway (2008) naive estimate of the firm's probability of default, PDEFAULT, we leave them out of our models when we use the probability of default to control for the borrower risk.

We now discuss our loan-specific variables $Y$. We include dummy variables equal to one if the loan has restrictions on paying dividends (DIVRESTRICT) and is secured (SECURED). All else equal, any of these features should make the loan safer, decreasing the spread, but it is well known that lenders are more likely to require these features if they consider the firm to be riskier (see for example Berger and Udell (1990)), so the relationship may be reversed. Loans with longer maturities (measured by the log of maturity in years, L MATURITY) may face greater credit risk, but they are more likely to be granted to firms that are thought to be more creditworthy; again, the effect on spreads is ambiguous. Larger loans (measured by $L A M O U N T$, the log of loan amount in hundreds of millions of dollars) may represent more credit risk, raising the loan rate, but they may also allow economies of scale in processing and monitoring the loan; again, the effect of this variable on loan spreads is ambiguous.

Because the purpose of the loan likely affects credit spreads, we include dummy variables for loans taken out for corporate purposes (CORP PURPOSES), to repay existing debt (DEBTREPAY), and for working capital (WORKCAPITAL). Similarly, we include dummy variables to account for the type of the loan-whether it is a line of credit (CREDIT LINE) or a term loan (TERMLOAN).

We also include bank-specific controls $Z$ that may affect banks' willingness or ability to supply funds. L ASSETS BK, the log of the bank's total assets, controls for bank size. Arguably, larger banks may be better-diversified or have better access to funding markets, leading to a lower cost of funds and (potentially) lower loan spreads. Similarly, a bank's return on assets $(R O A B K)$ may proxy for a bank's improved financial position, again leading to a lower loan spread. For the same reason, we expect the bank's capital-to-assets ratio, $C A P I T A L B K$, to be negatively related to loan interest rates. This relationship may also arise 
because, according to Boot et al. (1993), banks with low capital are more willing to consume reputational capital to build up financial capital and thus are more likely to renege on implicit guarantees, including the guarantee not to exploit their informational monopoly. On the other hand, since capital does not have the tax benefits of debt funding, that relationship may be reversed. Indicators of bank risk such as the volatility of return on assets (ROAVOL BK) or net loan charge-offs as a fraction of assets (CHARGEOFFS BK) may mean that the bank faces a higher cost of funds or is more willing to consume reputational capital to build up financial capital; either case suggests a positive impact on spreads. ${ }^{12}$

Finally, we control for the bank's holdings of cash and marketable securities as a fraction of total assets, LIQUIDITY BK, and for the bank's access to public debt markets through the fraction of the bank's subordinated debt to total assets, SUBDET BK. Banks with more liquid assets should find it easier to fund loans on the margin, leading to lower loan spreads. Similarly, banks with access to the bond market may be able to raise funds at a lower cost, again leading to lower loan spreads. A bank's subordinated debt may also act as a substitute for equity capital, in which case we should also expect the impact on loan spreads to be negative.

Our last set of controls, $M$, attempts to account for macro conditions and the conditions in credit markets that may also affect the spreads banks charge on their corporate loans. We control for the firm's cost to access the bond market by including the difference between the current yields on BBB- and AAA-rated bonds, BBB SPREAD. Last, we include the slope of the yield curve (SLOPE YC), computed as the daily yield difference between the five- and one- year zero-coupon bond, to control for expected changes in short-term rates. To account for the effect of additional factors at the yearly and quarterly levels, we add year and quarter fixed effects.

We estimate all our models with robust standard errors clustered at the bank level. We present the estimates from a pooled model, but we focus on models estimated with bank fixed effects to reduce concerns about unobserved heterogeneity at the bank level that may affect loan pricing policies. We also report the results of models estimated with bank-firm fixed effects. In this case, the difference in spreads comes from a difference in the loan pricing policy for the same bank and the same borrower. Further, we investigate the robustness of our findings when we include time-firm and time-firm-bank fixed effects to account for unobservable changes in loan demand (e.g., Khwaja and Mian (2008)). In this case, the identification comes either from comparing loan spreads for the same firm in the same time period across different banks (time-firm) or within the same bank (time-firm-bank).

\footnotetext{
${ }^{12}$ We use the volatility of return on assets $(R O A V O L B K)$ rather than the stock return because a large number of the banks in the sample are not listed on the stock market.
} 


\subsubsection{Cost of bond financing and the stance of the monetary policy}

To reduce concerns that the findings from the first part of our methodology are not specific to banks, we investigate the effect of monetary policy on bond spreads in the primary market. We consider a model similar to (1) but the dependent variable is equal to the bond spread (over Treasury) in the primary market on the bonds issued by firms in our sample. We explore whether riskier firms are also able to raise funding in the bond market at relatively lower costs (when compared to safer firms) in periods of low short-term interest rates, controlling for the same set of borrower- and macro-specific factors we use in our investigation of loan spreads. In addition, we account for the following set of bond-specific controls that are found to affect bond spreads: callable, convertible, with a floating rate and traded under Rule 144A.

\subsubsection{Banks' risk-taking and the monetary policy stance: Two-step procedure}

To assure us that the findings we derive in the first part of our methodology are indeed the result of a change in banks' risk appetite, we design several tests using the information banks provide in the SLOOS. This survey is particularly valuable for the purpose of this study because it contains quarterly information on banks' standards for approving loan applications in each quarter. We use this information to design the following two-step procedure. In the first step, we estimate the following probit model of the bank's lending standards:

$$
E A S I N G_{b, t}=c+\eta \cdot Z_{k, b, t-1}+\zeta \cdot M_{u, t-1}+\epsilon_{b, t} .
$$

$E A S I N G_{b, t}$ is a dummy variable that takes the value one in the quarters in which the bank indicates that its standards for approving loans were on net easier than in the three months earlier. We gather this information from the SLOOS which asks whether the bank's credit standards for approving applications for C\&I loans were, on net, tighter, easier, or unchanged from three months earlier.

In the second step, we use the residual of the first step in the following model of loan spreads:

$$
\begin{aligned}
& L \\
& \quad L O A N S P D_{f, l, b, t}=c+\alpha L O W R A T E_{t}+\beta B O R R I S K_{f, t-1}+\mu E A S I N G_{R E S b, t-1} \\
& \quad+\gamma L O W R A T E_{t} \times B O R R I S K_{f, t-1}+\phi E A S I N G_{R E S b, t-1} \times L O W R A T E_{t} \\
& \quad+\lambda E A S I N G_{R E S b, t-1} \times B O R R I S K_{f, t-1} \\
& \quad+\theta E A S I N G_{R E S b, t-1} \times L O W R A T E_{t} \times B O R R I S K_{f, t-1} \\
& \quad+\psi \cdot X_{i, f, t}+\nu \cdot Y_{j, f, t-1}+\eta \cdot Z_{k, b, t-1}+\zeta \cdot M_{u, t-1}+\epsilon_{f, l, b, t}
\end{aligned}
$$


We extract the generalized residual $E A S I N G_{R E S}$ from the first stage, following Gourieroux et al. (1987). These residuals are uncorrelated with the explanatory variables in equation (2) by construction. The inclusion of the generalized residual accounts for the correlation between the error terms in equations (2) and (3), suggesting that if these residuals play a role in loan spreads, it is not through changes in bank and macro factors. Rather, any impact of $E A S I N G_{R E S}$ on loan spreads is due to the monetary policy regime and unobservables associated with a bank's decision to ease its lending standards. Hence, the residual captures the bank's choice to ease the standards for approving loan applications for reasons other than its financial and macroeconomic conditions. We view this measure as a proxy for a bank's decision to rely on more lax standards for approving loan applications.

This part of our analysis has some similarities with Bassett et al. (2010), who use SLOOS to identify bank loan supply shocks. They extract the residuals from a model that estimates the lending standards on macro and bank factors. They then aggregate the residuals to a quarterly index to examine how exogenous bank supply shocks affect real gross domestic product (GDP) and core lending capacity in a VAR framework. We extract the generalized residuals instead at the bank-quarter level and examine their impact on loan pricing in times of high and low interest rates.

Our second-stage model investigates the impact of the bank's lending standards, or more specifically the impact of the bank's decision to ease its lending standards on the spreads it charges borrowers with different default risk when the short-term rate is low compared to when the short-term rate is high. The key effect of interest is identified by the coefficient on the triple interaction, $\theta$, which essentially is a difference-in-difference-in-differences estimator. This coefficient tells us whether loan spreads paid by risky borrowers (relative to safe borrowers) when banks ease their lending standards in periods of low interest rates is larger or smaller than loan spreads paid by risky borrowers (relative to safe borrowers) when banks ease their lending standards in periods of high interest rates.

We use a second question in the SLOOS survey to advance our investigation a step further in understanding the risk-taking channel of monetary policy. In addition to being asked whether the bank's credit standards for approving applications for C\&I loans were, on net, tighter, easier or unchanged from three months earlier, banks are also asked about the importance of "increased (reduced) tolerance for risk" when they ease (tighten) the terms for C\&I loans. Using this information, we construct the dummy variable RISKTOL, which takes the value one in the quarters a bank indicates that it eased its lending standards and that "increased tolerance for risk" was very important or somewhat important for easing the terms for C\&I loans. We then repeat the two-step procedure described above, using this proxy for the bank's risk tolerance. The residual from the probit model of RISK TOL $R E S$ captures 
the bank's decision to ease loan standards because of added risk tolerance for reasons other than its financial and macroeconomic conditions at the time of the loan applications. In other words, the residuals retrieved from the $R I S K T O L_{R E S}$ regression captures the bank's decision to ease its lending standards because of greater risk tolerance.

A key advantage of the RISKTOL RES over the EASING $R E S$ is that it isolates those periods when banks not only indicate that their lending standards are "looser" but they further specify that increased risk tolerance plays a key role in easing those standards. Therefore, if the stance of monetary policy affects banks' risk-taking incentives we should find clear evidence of this link when we use RISK TOL $L_{R E S}$ in our loan pricing model.

We use yet a third question from the SLOOS survey that asks the banks whether C\&I loan demand was strong or weak for reasons other than seasonal changes. Using these answers, we construct the dummy variable $D E M A N D W E A K$, which takes the value one in the quarters a bank indicates that $C \& I$ loan demand was weak for reasons other than seasonal changes. In one test, we add this new variable to our model of loan spreads to ascertain whether it helps to explain loan spreads in the presence of our controls. In another test, we follow a two-step procedure similar to the one described above. The dependent variable in the first step is the dummy variable $D E M A N D W E A K$. We leave out bank controls and consider only the set of macroeconomic controls and the dummy variable that captures the stance of monetary policy in the first step. For the sake of comparability, we use the generalized residual from the probit regression, $D E M A N D_{R E S}$, in the second-stage model of loan spreads. If firm and macroeconomic controls explain most of the differences in loan demand, then DEMAND $R E S$ should not affect the loan spreads banks charge risky and safe borrowers when short-term rates are low compared to loan spread differences when rates are high.

As in the first part of our methodology we focus on models estimated with bank fixed effects and on models estimated with bank-firm fixed effects.

\subsection{Sample characterization}

Table 1 presents the characteristics of our sample. There are 18,787 loans in our sample that were taken out by 4,223 publicly listed nonfinancial corporations between 1990 and 2010 from 235 banks. As is common in corporate samples, many variables are positively skewed, with mean values greater than median values. For example, the median firm is 13 years old and has a leverage ratio equal to 30 percent and a market-to-book value of 1.4 , whereas the mean firm is 20 years old and has a leverage ratio of 32 percent and a market-to-book value equal to 1.7. Several other variables, including the fraction of tangible assets, expenditures on $R \& D$ or advertising, interest coverage, stock return and probability of default are also positively skewed. The median firm has sales worth $\$ 722$ million, whereas the mean sales are 
$\$ 4,069$ million. With regards to credit rating, 44 percent of the loans in our sample are from rated borrowers. There is a slight predominance of loans in the sample from borrowers rated investment grade. Specifically, 24 percent of all loans are from borrowers rated investment grade and 20 percent are from borrowers rated below investment grade.

Turning our attention to the loan controls, we find that the loan amount is positively skewed, with a median of $\$ 64$ million and a mean of $\$ 204$ million. In contrast, the loan spread is negatively skewed with a median of 250 basis points over LIBOR and a mean of 247 basis points over LIBOR. The median maturity is four years. Most of the loans are secured and have dividend restrictions, and virtually all of them are senior. Roughly a third of the loans (34 percent) are for corporate purposes. With regards to the type of contract, 28 percent of loans are term loans, and 54 percent are credit lines. The lead arranger holds 42.1 percent of the loan.

The average bond issue is as large as $\$ 271$ million and the average credit spread is 136 basis points. Having almost 11 years of maturity on average, we document that 9 percent of the bonds are callable, 11.8 percent are convertible, 19.1 percent are traded under Rule 144A, and 6.2 percent have a variable coupon. We note that $80 \%$ of the public firms in the syndicated loan sample are also in the bond sample.

Next, we consider the set of bank controls we use in our study. We measure these controls at the holding company level, and not at the bank level, to capture any potential effects that may arise from ownership transfers between entities of the same holding company. For ease of exposition, though, we will continue to refer to these as bank controls. Banks are significantly larger than their borrowers: median bank assets are $\$ 272$ billion, and mean bank assets are $\$ 574$ billion. The average bank has an equity-to-assets ratio of about 8 percent, and is funded predominantly with deposits. The average deposit-to-assets ratio of the banks in the sample is about 65 percent. In contrast, subordinated debt accounts for only about 1 percent of the funding used by the average bank. The return on assets and the net charge-offs have a mean and a median of about 0.1 percent. The return on assets volatility, however, is strongly negatively skewed with a mean of 0.2 percent and a median of 0.1 percent.

Looking at the lending standards variables from the SLOOS, we note that in each quarter on average about 7 percent of the banks indicate that their standards for approving loans are on net easier than in the previous quarter. Furthermore, on average about 5 percent of banks specifically indicate that "increased tolerance for risk" was very important or somewhat important for easing the terms for C\&I loans. During the sample period, on average in each quarter about $28 \%$ percent of banks indicate that demand for C\&I loans was weak for reasons other than seasonal changes. As we will show in the next section, these variables play a very important role in identifying the risk-taking channel of monetary policy. 
The mean value of the BBB SPREAD is $1.882 \log$ points and the mean slope of the yield curve is 0.836 .

\section{Do risky firms receive a loan discount when interest rates are low?}

In this section, we study the bank risk-taking channel of monetary policy by investigating how banks' lending policies vary with the stance of monetary policy. We begin by comparing loan spreads between low- and high-interest-rate regimes. Next, we investigate whether the risk of borrowers affects loan spreads differently in low and high regimes.

\subsection{Loan spreads and the federal funds rate}

Table 2 reports our first set of regressions. This table aims to show the impact of short-term interest rates on loan spreads by distinguishing periods of low- and high-interest-rate regimes. That table also aims to show the impact on loan spreads of the two measures of firm risk we use to investigate the bank risk-taking channel of monetary policy-credit rating and probability of default.

We classify interest rates as "low" if the federal funds rate at the time of the loan is below the sample median. As we can see from Figure 1, which plots the federal funds rate over the sample period, the low period is dominated by the 2000s. In contrast, the "high" period is dominated by the 1990s.

Models (1) through (3) control for the credit rating of the borrower by distinguishing borrowers that are rated below investment grade from those that are unrated and those that are rated investment grade (the omitted category). Models (1) and (2) have bank fixed effects and model (3) has bank-firm fixed effects. Given that some loan controls may be endogenous we first estimate our model of loan spreads without these controls (model 1) and then investigate what happens when we include them in the regression (model 2). Models (4) though (6) follow a similar structure but the focus is on the probability of default of the borrower. All the models reported in Table (2) include firm-, bank, and macroeconomic controls. Throughout, the reported robust standard errors are clustered by bank.

Two important results stand out in Table 2. First, in periods when the federal funds rate is low, banks charge higher corporate loan spreads. $L O W$ is positive and highly statistically significant in all models of the table. Second, riskier borrowers, as measured by their credit rating or by their probability of default, pay higher spreads on their loans. This finding holds both when we compare loan spreads across borrowers and when we compare loan spreads within borrowers (models 3 and 6). B GRADE is positive and statistically significant in the 
first three models of the table, and $P D E F A U L T$ is positive and statistically significant in the last three models of the table. The results of Table 2 also appear to confirm that some of the loan controls are endogenous since the coefficients on B GRADE and P DEFAULT decline when we add these controls to our models. Most importantly, adding these controls does not affect the statistical significance of either one of these measures of borrower risk.

According to our base model, which accounts for macroeconomic, firm- and bankspecific controls as well as for bank fixed effects (model 1), borrowers rated below investment grade pay on average a 127 percent higher spread than borrowers rated investment grade. ${ }^{13}$ This difference declines to 100 percent when we expand our set of controls to account for loan-specific characteristics (model 2), and it declines further to 50 percent when we replace bank-fixed effects with bank-firm fixed effects (model 3). We find a similar pattern when we focus on the borrower's probability of default. According to our base model (model 4), one percent increase in the probability of default leads to a 250 percent higher spread on average. In columns (5) and (6), where first loan controls and then loan controls and bank-firm fixed effects are included, a one-standard-deviation increase in the probability of default results in an 164 percent and a 106 percent higher spread, respectively.

Most of the controls in our models have reasonable effects on loan spreads and are generally consistent with other studies of loan spreads. ${ }^{14}$ Looking at our firm controls, we see that older and larger firms pay lower spreads, as do firms with more tangible assets or high excess stock returns. Firms with higher interest coverage and those with more growth opportunities also pay lower spreads on their loans. In contrast, firms with higher leverage or stock volatility pay higher spreads. The only firm control that is statistically significant and contrary to expectations is the profit margin as it indicates that firms with a higher profit margin pay higher spreads on their loans.

With regard to the loan controls, banks appear to extend larger loans as well as longerterm loans to safer borrowers. In contrast, and in line with the evidence offered by Berger and Udell (1990), they generally demand that loans to riskier borrowers be secured, thereby explaining why these loans carry lower spreads. A similar reason explains why loans that result in dividend restrictions carry higher spreads.

In regard to our set of bank controls, those that are statistically significant are generally consistent with expectations. Like Hubbard et al. (2002) and Santos and Winton (2011) we too find that banks with higher equity-to-assets ratio charge lower spreads. Banks with better ratings also charge lower spreads. By contrast, banks with higher chargeoffs demand higher

\footnotetext{
${ }^{13} \mathrm{An}$ increase of 127 percent in the log loan spread translates to an increase of exp(-0.824)-1.

${ }^{14}$ For other studies of loan spreads see, for example, Santos and Winton (2008), Hale and Santos (2009), and Santos (2011).
} 
corporate loans spreads. ROA volatility and the ratio of deposits over assets are generally not significant, but when they are significant, they have an unexpected impact on loan spreads. The remaining bank controls (assets, subdebt, ROA and liquidity) do not appear to play a role in loan spreads, at least after we control for bank ratings.

Finally, the other two macroeconomic controls we include - the triple-B spread in the bond market and the slope of the Treasury yield curve- have the expected positive effects on loan spreads. However, while the triple-B is highly significant in all models, the slope of the Treasury yield curve is significant only in models (5) and (6).

Looking ahead, we emphasize that banks charge higher spreads to riskier borrowers and that on average they charge higher spreads when the federal funds rate is low compared to when it is high. Next, we investigate whether riskier borrowers benefit from a "discount" vis- $\grave{a}$-vis the loan rates banks charge safer borrower in periods when the federal funds rate is low. In the interests of space, in what follows, we do not report the results for the various firm-, loan-, and bank-specific controls or the results for the macroeconomic controls.

\subsection{Risk structure of loan spreads and the federal funds rate}

In this section, we begin our investigation of the bank risk-taking channel of monetary policy by analyzing whether the risk premium that banks charge riskier borrowers varies with the stance of monetary policy. We hypothesize that if monetary policy affects banks' risk-taking incentives, the spread difference between risky and less risk borrowers in times of low interest rates vis-a-vis times of high interest rates decreases. To test this hypothesis, we add the interaction term $L O W R A T E \times B G R A D E$ in models (1) to (3) in Table 3 and $L O W R A T E \times$ $P$ DEF AULT in models (4) to (6). All models are analogous to those in Table 2: model (1) omits loan controls and has bank fixed effects, model (2) adds loan controls and has bank fixed effects, and model (3) has loan controls and bank-firm fixed effects. The estimates on loan-, firm-, and bank-specific controls are unreported because they are very similar to those already discussed in Table 2.

The results of our tests indicate that it is "advantageous" for riskier borrowers to take out loans in periods of low interest rates. This finding is consistent with the existence of a bank risk-taking channel of monetary policy. The sign on the interaction term $L O W R A T E \times B G R A D E$ in columns (1) through (3) is negative and significant for all three models. This result implies that the difference between the loan spread of below-investmentgrade borrowers and investment-grade borrowers is lower when short-term interest rates are low than when they are high. In model (1), borrowers rated below investment grade pay only 114 percent higher spreads than what investment-grade borrowers pay when short-term interest rates are low. However, when the interest rates are high, they pay 145 percent more which 
is significantly higher than in the low regime. Similarly, in model (2), below-investment-grade borrowers pay 87 percent higher spreads than investment-grade borrowers when interest rates are low, and 117 percent more when interest rates are high. Likewise, in model (3), the percentage spread difference between below-investment-grade and investment-grade borrowers is 50 percent in times of low interest rates and 65 percent in high-interest-rate regime. Across all three models, the estimates on LOW RATE $\times U N R A T E D$ and $L O W R A T E \times B G R A D E$ have similar magnitudes, which suggests that the unrated borrowers experience underpricing similar to the below-investment-grade borrowers.

A potential concern with these results is that they rely on credit ratings. If credit ratings do not accurately reflect how changes in the stance of monetary policy affect the risk of borrowers, this could potentially explain our findings. Our next test addresses this concern by focusing on the borrower's probability of default. This measure of risk has two important advantages over the credit rating. It is computed from market data, and consequently it is a forward-looking measure of risk. As such, it is more likely to account for any effect that the stance of monetary policy may have on the borrower's risk of failure. Furthermore, in contrast to the credit rating which exists for only 50 percent of the borrowers in our sample, the probability of default is available for all the borrowers. For these reasons, we will rely on the borrower's probability of default in the rest of the paper.

The results of our tests using the borrower's probability of default are reported in models (4) through (6) of Table 3. The key insight of our investigation based on credit ratings continues to hold when we use the borrower's probability of default. The point estimate on $L O W R A T E \times P D E F A U L T$ is negative in all models, although it is statistically significant only in models (5) and (6). In model (4) where the set of loan controls is omitted the estimate of the interaction term is insignificant, highlighting the importance of these variables. In model (5), one percent increase in the probability of default is associated with a 148 percent increase in spreads in the low-interest-rate regime and with a 188 percent increase in the high-interestrate regime. When we control for unobservable factors at the bank-firm level, risky borrowers enjoy 75 percent higher spreads in the low regime and almost 200 percent higher spreads in the high-interest-rate regime. ${ }^{15}$

Our finding that loan spreads are less sensitive to the borrower's risk of default in times of low short-term rates than in times of high short-term rates is consistent with the idea that banks discount risk in periods of monetary policy easing. In other words, our finding is

\footnotetext{
${ }^{15}$ We estimate a more comprehensive specification (unreported) in which all variable in models (5) and (6) in Table 3 are interacted with $L O W R A T E$. If monetary policy regimes affect loan spreads through other characteristics than the probability of default, this specification will account for it. The results suggest that the effect of the probability of default on loan spreads continues to hold above and beyond the joint effects of firm, bank, and loan factors and their interaction terms with the monetary policy regime.
} 
consistent with the existence of a bank risk-taking channel of monetary policy. ${ }^{16}$ It is possible, however, that the difference in the sensitivity of loan spreads to borrowers' risk is biased due to omitted variables correlated with monetary policy regimes. Another concern is that the result can be attributed to changes in the demand for loans rather than to changes in the supply of loans. Controlling for the loan characteristics, a large number of time-variant firm and bank controls, and time-invariant factors at the bank and bank-firm levels as well as macroeconomic conditions at the time of loan origination should mitigate those concerns. In the remainder of the paper, we report the results from several tests that we design to rule out various alternative explanations to our finding on the effect of monetary policy on banks' risk-taking incentives.

\section{Can credit demand explain risky borrowers' loan discount?}

The estimate of $L O W R A T E \times P D E F A U L T$ may be driven by credit demand and credit supply. For example, in times of low interest rates poor economic conditions affect risky borrowers relatively more (Erel et al. (2012). Due to weaker investment opportunities and hence weaker demand for credit, the loan spreads may be relatively lower for risky borrowers. We provide three qualitatively different tests below that argue that credit demand is not driving the result.

First, if risky borrowers decrease demand for credit in times of low interest rate regimes, observing a discount in loan pricing for these borrowers may be the result of decreased demand for credit. One way to rule out this plausible story is to examine loan quantities. If the credit supply curve shifts outward, holding everything else equal, we should observe lower prices of credit to be accompanied with greater credit amount at any given price. Alternatively, if lower prices are observed together with lower loan amounts, then supply effects are difficult to reconcile. In Table 4 we estimate the same specification as in equation (1) except for having loan amounts as a dependent variable. ${ }^{17}$ In columns (1) and (2) we use credit rating as a

\footnotetext{
${ }^{16}$ We have also investigated whether the bank risk-taking channel is present when interest rates are falling. We repeat the exercise we undertake in Table 3, but this time we identify monetary policy easing to be present in periods of falling interest rates and tightening to be present in periods of increasing interest rates. Periods of falling rates include loans originated from 1 January 1990 to 04 September 1992; 1 February 1995 to 30 January 1996; 29 September 1998 to 14 November 1998; 16 May 2000 to 25 June 2003; 17 August to 30 December 2010. Basically, looking at Figure 1 when the policy rate is downward sloping monetary policy is defined as easy and when it is upward sloping monetary policy is considered to be tight. We omit loans originated from January 31, 1996, to September 29, 1998 because during that period the rates cannot be clearly identified either as falling or increasing. Consistent with our previous results, we find that in periods of falling short-term rates it is relatively less expensive for riskier borrowers to take out loans than when short-term rates are going up.

${ }^{17}$ An additional control that is not part of the loan spread regression is the percentage share that each lead arranger holds in the loan. This variable is missing for almost half of the observations. We include the observations with the missing category in the regression to avoid sample selection issues. Importantly, the results remain when we omit this variable or employ different rules for filling in the missing information (e.g.,
} 
measure of risk and in columns (3) and (4) we use the probability of default. The results show that below-investment grade borrowers obtain larger loans than investment-grade borrowers when interest rates are low. A similar effect is observed in column (2). In columns (3) and (4), we see that on average the relationship between probability of default and loan amount is negative. However, it is less so for risker borrowers when interest rates are low, i.e., the estimate on $L O W R A T E \times P D E F A U L T$ is positive and significant. In times of low monetary policy, a relative price decline together with an increase in loan amounts for risky borrowers is consistent with credit supply effects, related to the bank risk-taking channel.

Second, to account for time-variant unobservable changes in loan demand we include time-firm fixed effects (e.g., Khwaja and Mian (2008)). This allows us to control for loan demand shocks within a specific time period. The identification comes from comparing loan spreads for the same firm in the same time period across different banks. If demand shocks are correlated with the monetary policy regime and/or a firm's riskiness including time-firm fixed effects would remove away the effect of credit demand on LOW RATE $\times$ P DEFAULT. In column (1) of Table 5 we report the coefficients of interest. To ensure that the same firm takes more than one loan over a specific time period, we define time as a three year period. Since not all firms take more than one loan in the specified period we use as many as half of the observations. As in the previous section, the conclusion that the loan spread between risky and safe borrowers is lower during easy monetary policy regime continues to hold. In column (2), we go a step further and include time-firm-bank fixed effect. The identification comes from comparing spreads within the same firm, bank and time period. In such a way we control for unobserved time-varying heterogeneity at the bank-firm level. The results further reinforce the above conclusion.

Third, we investigate whether our results hold across borrowers of different size. To that end, in columns (3) through (6) of Table 5, we estimate loan spread regressions separately for large and small firms. This test is important because large and small firms may be subject to different unobserved firm-specific demand shocks that happen to be correlated with monetary policy regimes. Therefore, if the estimate of $L O W R A T E \times P D E F A U L T$ is correlated with uncontrolled demand shocks that are different for large and small firms, we run the risk of observing that the estimate is negative and significant either for large or small firms. This would suggest then that demand rather than supply factors are at play. We observe in columns (3) and (4) (bank fixed effects) and in columns (5) and (6) (bank-firm fixed effects) that the estimates are negative and significant for both large and small firms. As far as the magnitude of these estimates is concerned, large firms experience a greater undercut when interest rates are low than small firms do. One possible explanation is that large firms may have alternative

the average percent of shareholdings by bank within a year). 
sources of financing and that banks decrease their price more aggressively to provide incentives to borrow. Alternatively, according to the broad credit channel, loose monetary policy causes borrowers' balance sheets to improve their collateral values. To the extent that small firms improve their net worth relatively more when interest rates are low, we would expect that these firms are more affected by this channel. This explanation, however, is not supported by the data because it is large risky firms that experience a greater cut than small risky firms.

\section{$5 \quad$ Other robustness tests}

In this section, we report additional robustness tests of our key findings. In the interest of space and because of the advantages that the probability of default has over the credit rating, we use the borrower's probability of default in the robustness tests.

\subsection{Probability of default after loan origination}

Finding that loan spreads are relatively lower for riskier borrowers in times of low versus high interest rates is consistent with a bank risk-taking channel of monetary policy, but it could also be the result of the following situation. Loan spreads of risky borrowers are relatively lower when interest rates are low because banks expect these borrowers to improve their risk profiles in the future. Similarly, when interest rates are high, banks may expect firms to deteriorate their risk profiles. Recall that our measure of borrower risk - the borrower's probability of default - aims at capturing the borrower's risk of default in the year following loan origination and that the average maturity of the loans in our sample is four years. To address this concern, we examine whether the probability of default changes one, two, and three years after loan origination compared to the year of origination. In Table 7 we report results for the first, second, median, and the last loan. The median number of loans within a firm is three. We estimate the probability of default regressions during and after loan origination periods. In the upper panel we focus on loans originated in the low-interest-rate regime, and in the lower panel we focus on loans originated in the high-interest-rate regime.

In the upper panel, we observe that the probability of default is not statistically different for one, two or three years after loan origination compared to the year of loan origination. We observe in column (4) that the probability of default is actually higher after a firm's last loan is originated. Looking at the lower panel of the table, we do not detect any systematic pattern of the probability of default after loan origination in the high-interest-rate regime. These results indicate that banks do not give an interest rate discount to risky borrowers in periods of low interest rates relative to periods of high interest rates because they expect risky borrowers to have lower or higher probability of default in the near future. 


\subsection{Economic conditions}

We investigate the role of economic conditions. Our loan spread findings can be the result of the economic conditions rather than the result of monetary policy per se as both are arising endogenously. Of course, the policy rate and macro conditions evolve endogenously in the economy and isolating economic from monetary policy fluctuations would require a setting in which monetary policy is exogenous to loan demand and supply.

In Table A1 in Appendix 3 we include various measures of economic conditions and look at whether the estimate on $L O W R A T E \times P D E F A U L T$ is still preserved. In column (1), we add the quarterly GDP growth rate $(G D P)$ and its interaction with the borrowers's probability of default. We find that the estimates on $L O W R A T E \times P D E F A U L T$ in columns (1) and (2) preserve their negative sign and are comparable to those in Table 3, columns (5) and (6). The estimates on $G D P \times P D E F A U L T$ in models (1) and (2) take a positive sign suggesting that high GDP growth and high probability of default are associated with higher spreads. ${ }^{18}$

In columns (3) and (4), we use negative output gap (NEG OUTPUT GAP) as an alternative measure of economic conditions. This variable is the negative value of the difference between the actual GDP and the estimated potential GDP according to the Congressional Budget Office. The results are very similar to those in columns (1) and (2) with the exception that the estimate on $L O W R A T E \times P D E F A U L T$ loses its significance in the specification with bank fixed effects. In columns (5) and (6) we identify recession periods as defined by the National Bureau of Economic Research and find that the estimates on LOW RATE $\times$ P DEFAULT are preserved. Overall, using three different measures of economic conditions does not distort the impact of borrower risk on loan spreads in times of low interest rates. This is not to say that economic conditions do not affect loan spreads but rather that they contribute to those spreads together with the stance of monetary policy.

In columns (7) and (8), we introduce the Chicago Fed National Activity Index as a proxy for economic activity. This index tracks periods of economic expansion and contraction. ${ }^{19}$ We note that including the index in the loan spread regression does not affect our coefficient

\footnotetext{
${ }^{18}$ In unreported analysis, we have estimated a model with a triple interaction term between GDP, LOW RATE and $P$ DEF AULT. Our results continue to hold. We have also defined high and low GDP regimes similar to the monetary policy regimes. The unreported results are consistent with the specifications in Table A1.

${ }^{19}$ The economic indicators used for the index are from several data sources: production and income data, employment and unemployment hours, personal consumption and housing, and sales, orders and inventories. All data series are adjusted for inflation. Overall, the index is a weighted average of 85 economic indicators. It is observed that if the three-month moving average falls below -0.7 , there is an increasing likelihood that a recession has begun. The idea behind the index construction is that there is some factor common to all of the various inflation indicators, and it is this common factor, or index, that is useful for predicting inflation. Research has found that the CFNAI provides a useful gauge on current and future economic activity and inflation in the United States.
} 
of interest on $L O W R A T E \times P D E F A U L T$.

These results should alleviate concerns that the results in Table 3 can be explained by cycles of economic activity that overlap with monetary policy. To reduce these concerns further, we investigate the robustness of our findings to the importance of the economic conditions by looking at lending of U.S. banks to Canadian firms. Specifically, we investigate whether U.S. banks also undercut loan spreads to riskier borrowers in Canada in periods when U.S. interest rates are low.

\subsubsection{U.S. bank lending to Canadian firms}

If U.S. banks are affected by U.S. monetary policy, they are likely to transfer this effect to both their U.S. borrowers and their Canadian borrowers. The reverse, that is, the impact of loan demand by Canadian firms and the Canadian economic environment on U.S. monetary policy, is not likely to happen. Therefore, if we find that U.S. banks have the same pricing policy for Canadian borrowers as for U.S. borrowers, this will provide stronger support that our results are not driven by the response of monetary policy to demand shocks and vice versa. This is subject to the assumption that the U.S. and Canadian economies are not affected by the same demand shocks. To investigate this hypothesis, we first identified the loans in Dealscan that U.S. banks extended to nonfinancial corporations operating in Canada. ${ }^{20}$

Looking at Table A2 in Appendix 3, below-investment-grade Canadian firms that borrow from U.S. banks pay relatively less than their investment-grade counterparts in times of low interest rates in the United States. This result holds across different specifications and it is similar to the result we find for U.S. borrowers. Since the Canadian economic environment is less likely to influence U.S monetary policy than the economic environment in the U.S., our evidence that U.S. banks offer an interest rate discount to both riskier corporations operating in the U.S. and riskier corporations operating in Canada when short-term interest rates are low in the United States adds important support to our evidence on the existence of a bank risk-taking channel in the U.S.

\footnotetext{
${ }^{20}$ We identify 6,127 loans taken out by 1,669 Canadian corporations. Since only 525 of these corporations are publicly listed, we estimate our model of loan spreads both with and without firm controls. For the same reason, in this test we proxy for the risk of the borrower by its credit rating and do not consider a specification which uses the borrower's probability of default. Even though we identify 525 Canadian publicly listed firms, the probability of default data is available for only 150 of these firms. Also, because Canadian borrowers have fewer loans than their American counterparts, we estimate our model of loan spreads only with bank fixed effects.
} 


\subsection{Monetary policy shocks}

Identifying the impact of monetary policy on loan rates is subject to simultaneity between monetary policy and economic development as the federal funds rate respond to information about future developments in the economy. Romer and Romer (2004) takes into account this type of endogeneity by removing anticipatory movements from the intended funds rate. Specifically, they examine narrative accounts based on the minutes and statements from the Federal Open Market Committee (FOMC) meetings to isolate desired policy change. Next, the intended federal funds rate is regressed on the Federal Reserve's internal forecasts of inflation and real activity. The residuals from this regression are the monetary policy shocks, interpreted as changes in the intended federal funds rate that are not made in response to forecasts of future economic conditions. ${ }^{21}$

Table 8 reports the results of a regression specification similar to that in Table 3 except for the definition of monetary policy. In columns (1) and (2) monetary policy easing is based on Romer and Romer monthly shocks and in columns (3) and (4) it is based on a Tayortype rule. Looking at columns (1) (with bank fixed effects) and (2) (with bank-firm fixed effects), the loan spread for riskier borrowers is relatively smaller for periods of easing versus periods of tightening. This evidence is consistent with our previous results. The advantage of this measure is that it removes away anticipatory changes in the economic conditions which affect monetary policy. Easing (ROMER SHOCK) is a dummy variable that takes one for negative residuals and zero otherwise. ${ }^{22}$ In columns (3) and (4) the monetary policy shocks are based on a deviation of the actual federal funds rate from from a Taylor-rule predicted funds rate. The rule includes inflation and unemployment less the Congressional Budget Office natural unemployment rate. The results suggest that the loan spreads are lower for more risky borrowers when monetary policy shock indicates easing according to the Taylor rule (TAYLOR SHOCK).

Overall, when using two different approaches to remove the anticipated economic development that affects the federal funds rate our conclusion that risker borrowers experience a discount when monetary policy is easy remains.

\footnotetext{
${ }^{21}$ The variables that are included in the regression of the intended federal funds rate are GDP deflator, real GDP and unemployment. Romer and Romer (2004) provide monetary policy shocks up to the end of 1996 . We thank Christopher Crowe for making the data from 1990 to 2008 available to us. For details see Barakchian and Crowe (2010).

${ }^{22}$ We drop observations around the zero cutoff point to avoid misclassification of easing and tightening regimes. The same applies for the Taylor rule shocks. The results remain when we do not exclude these observations.
} 


\section{Do bond investors also offer a discount to riskier borrowers?}

We have already ruled out that demand alone explains the interest rate discount that riskier borrowers enjoy (relative to safer borrowers) in the loan market in periods of low short-term interest rates. Notwithstanding this evidence, one may still wonder if this discount is bank driven or alternatively it is the result of omitting unobservable factor correlated with the borrower's risk of default.

One way to address this concern is to see if riskier borrowers also enjoy a discount when they raise funding in the bond market in periods of low short term interest rates. Some of the reasons put forth in the literature for banks to seek on more risk in periods of easing monetary policy arguably also apply to bond investors. However, unlike banks bond investors are not protected by the safety net and hence are less likely to become as risk-taking as banks when monetary policy is loose. To that end, we investigate the effect of monetary policy on bond spreads (over Treasury).

We report the results of our investigation of bond spreads in Table 6. We control for issue and issuer characteristics. We use the same set of firm controls as in the loan regressions (see Table 3). In columns (1) and (2) the reported specifications control for several issue features such as whether the bond is callable, convertible, placed privately and/or has a floating coupon. In columns (3) and (4) we drop bonds that are callable, convertible and floating coupon bonds. Our coefficients of interest are LOW RATE $\times B$ GRADE and LOW RATE $\times P$ DEF AULT.

In columns (1) and (3) we observe that the estimate on the interaction term is positive and significant suggesting that risky issuers are priced relatively higher when interest rates are low. This is exactly the opposite to the evidence of loan spreads. Similarly, in columns (2) and (4) where probability of default is used, we observe positive interaction terms. In columns (5) and (6) we find similar evidence when privately placed bonds are excluded. It appears therefore that in contrast to banks, the risk appetite of bond investors - usually insurance companies, pension funds and other investment managers - is not affected by the stance of the monetary policy in the same way. This evidence adds to our interpretation that the interest rate discount riskier borrowers enjoy (relative to safer borrowers) in the loan market when short-term interest rates are low is driven by banks' risk-taking incentives. We find evidence that risk-taking in times of low interest rates is not present in the bond market, however a thorough investigation of the difference between the syndicated loan and the bond market is beyond the scope of this paper.

While this exercise confirms that risk-taking behavior is pertinent to banks, it does not

allow to pin down its source. For this reason, in the next section we attempt to provide direct evidence that the interest rate discount is indeed driven by banks' risk-taking incentives. 


\section{Using SLOOS to identify bank risk-taking}

We have interpreted the interest rate discount to riskier borrowers (relative to safer borrowers) in periods of low short-term interest rates as evidence of the bank risk-taking channel of monetary policy. While we have already provided solid evidence that this discount is bank driven, one could still wonder if it is indeed driven by banks risk appetite.

To confirm that the interest rate discount riskier borrowers enjoy (relative to safer borrowers) when short-term interest rates are low derives from a change in banks' risk appetite, in this section we report the results of the two-step procedure we developed using the information banks provide in the Senior Loan Officers Opinion Survey on their lending standards. That information is valuable for an investigation of the bank risk-taking channel of monetary policy because it allows us to extract a bank-specific measure of risk appetite that by construction is not driven by changes in banks' balance sheets and macroeconomic conditions.

\subsection{Bank lending standards and the federal funds rate}

We begin this part of our investigation by considering the information banks provide in response to the SLOOS question of whether they have eased their standards for approving loans. ${ }^{23} \mathrm{We}$ estimate a probit model in the first stage of our two-step approach in which the dependent variable is a categorical variable that takes the value one if the bank indicates it has eased its lending standards and zero otherwise. The independent variables of the first-stage model are the set of bank and macro factors described in Section 2.2.3. ${ }^{24}$

We construct the generalized residuals following Gourieroux et al. (1987) and use them as a measure of the bank's easing of lending standards in the second stage regression. As we cannot point to the direct reason for easing, we view this measure as a more general proxy for soft lending standards. One advantage of using this measure of bank lending standards is that it allows us to pin down directly the propensity to ease at the bank level. In our previous tests, we find suggestive evidence of the bank risk-taking channel- the sensitivity of loan spreads to the borrower's probability of default in times of low versus high short-term rates. However, without using a proxy of banks risk tolerance, we cannot be sure whether risk-taking is at play. Another advantage of that measure is that it is not built on bank balance sheet information, but it comes instead from an alternative source of bank information - the survey of bank lending

\footnotetext{
${ }^{23}$ The exact survey question is: "Over the past three months, how have your bank's credit standards for approving applications for C\&I loans or credit lines - other than those to be used to finance mergers and acquisitions - to large and middle-market firms changed (annual sales of $\$ 50$ million or more)?"

${ }^{24}$ We do not report the results of the first stage in the interest of space, but they are available from the authors upon request. The policy rate does not enter into the first stage because we are interested in exploring the joint impact of the monetary policy regime and the residual bank risk tolerance in the second stage.
} 
standards. These data permit the extraction of a cleaner measure of banks' incentives to ease their lending standards based on responses of bank officers.

Table 9 reports the results of the second-stage regressions on loan spreads. In column (1), the estimates on $E A S I N G_{R E S}$, and PDEFAULT $\times E A S I N G_{R E S}$ are not significant, suggesting that softer lending standards neither alone nor through a firm's probability of default affect loan spreads. The same result is preserved when bank-firm fixed effects are included in column (2).

Because we are interested in the differential impact of $P D E F A U L T \times E A S I N G_{R E S}$ across low and high monetary policy regimes, in columns (3) and (4) we introduce regression models that allow for the complete interaction among P DEFAULT, EASING $G_{R E S}$ and $L O W R A T E$. The estimate on $E A S I N G_{R E S} \times L O W R A T E \times P D E F A U L T$ shows whether $P D E F A U L T \times E A S I N G_{R E S}$ differs across monetary policy regimes. In column (3), where bank fixed effects are considered, the estimate on $E A S I N G_{R E S} \times L O W R A T E \times P D E F A U L T$ is -1.223 and it is statistically significant. The interpretation is that when interest rates are low, easing banks charge riskier borrowers relatively less than tightening banks compared to the high regime of monetary policy. The same conclusion holds when we add bank-firm fixed effects in column (4).

One concern with these results is that banks ease their lending standards only when interest rates are low. When comparing the distribution of $E A S I N G_{R E S}$ between high and low monetary policy regimes, we find that the parameters of the two distributions are very similar. This finding is important because it allows us to isolate the effect of $L O W R A T E \times P D E F A U L T$ from $E A S I N G_{R E S} \times L O W R A T E \times P D E F A U L T$.

The significant coefficient on the triple interaction term in column (3) indicates that loan spreads for risker borrowers originated by easing banks are lower in times of low interest rate regime relative to times of high interest rate regime. To better understand the interpretation of the triple interactions term, In Table 10 we compute the marginal effects of the probability of default on spreads for LOW and HIGH interest rate regimes separately for easing and tightening banks. For low interest rate regime and easing banks (column (1)), the $(\log )$ difference in spreads between risky (probability of default is 0.2 ) and safe (probability of default is 0.05 ) borrowers is 0.108 . When banks tighten their lending standards this loan spread differential is 0.144 (column (2)). Hence, easing banks charge risky borrowers relatively less (-0.035) than tightening banks when the interest rates are low.

On the contrary, when the interest rates are high easing bank price risky borrowers relatively more than tightening banks (column (3-4)). The difference-in-difference-in-differences estimate reported in column (5) is equal to -0.274 . It indicates that easing vis-a-vis tightening banks price risky borrowers less when rates are low compared to when the rates are high. 
The difference-in-difference-in-differences estimate corresponds to the average triple interaction term in columns (3) of Table 9.

\subsection{Bank risk tolerance and the federal funds rate}

Our finding that easing banks put less weight on risk when they set rates on loans they extend in periods of low short-term rates adds important support to our prior assertion that the interest rate discount riskier borrowers enjoy when they borrow in these periods is the result of an increase in banks' risk appetite. The next test considers the information banks provide in response to a question in SLOOS which is even more relevant for our purposes because it is about the importance of "increased tolerance for risk" when they ease the terms for C\&I loans. ${ }^{25}$ The response of this question is particularly valuable to our investigation because it captures precisely the bank's appetite for risk. While the residuals in Table 9 capture risk appetite due to easing of the lending standards in general, easing due to greater risk tolerance goes a step further to clarify the exact reason for such easing.

Using the information from this second question, we construct RISKTOL RES. This is the residual from a probit regression that builds on the indication that a bank's "increased tolerance for risk" played an important role in the decision to ease its lending standards for C\&I loans. We then use this information in our model of loan spreads similar to what was done with $E A S I N G_{R E S}$. The second stage results that use RISKTOL RES are reported in Table 11. In column (1), the negative sign on $P D E F A U L \times R I S K T O L_{R E S}$ suggests that banks that are easing because they have become more risk tolerant charge riskier borrowers relatively less than other banks. In column (2), where bank-firm fixed effects are included, this estimate is purged away suggesting that banks' underpricing behavior is attenuated when we account for repeated relationships between borrowers and banks. In column (3), the negative sign and large magnitude on the estimate on $R I S K T O L_{R E S} \times L O W R A T E \times P D E F A U L T$ suggests risk tolerant banks lower spreads relatively more for risky borrowers in the low monetary policy regime compared to the high interest rate regime. The interpretation is that more risk-taking banks offer lower spreads to relatively less risky borrowers in low interest rate regimes relative to high interest rate regimes.

The results of model (3) imply that the estimated loan spreads for risker borrowers charged by banks with more appetite for risk is 189 percent lower in times of low interest rates than in times of high interest rates. The results of model (4), which account for bank-firm fixed effects instead of bank fixed effects, in turn imply that the average loan spread for risker borrowers charged by banks with more appetite for risk is 32 percent lower in times of low

\footnotetext{
${ }^{25}$ The exact survey question is: "If your bank has eased its credit standards or its terms for C\&I loans or credit lines over the past three months, how important have been increased tolerance for risk?"
} 
interest rates compared to times of high interest rates.

Our tests based on banks' answers to the SLOOS provide two critical pieces of evidence in support of the bank risk-taking channel. The first piece of evidence shows that riskier borrowers enjoy relatively lower spreads when they borrow in periods of low interest rates from banks that soften their lending standards relative to periods of high interest rate regimes. The second piece of evidence shows that riskier borrowers enjoy relatively lower spreads when they borrow in periods of low interest rates from banks that indicate they soften their lending standards because they have a greater appetite for risk.

\subsection{Loan demand: Evidence from SLOOS}

In this section, we take another look at the role of loan demand. As we noted above, this is important because a portion of the risk-taking effect may be attributed to demand factors as opposed to bank risk taking per se. In Section 4, we reported several tests that aim to ameliorate concerns that demand for loans drives the results. In this section, we investigate the role of loan demand by using banks' responses to the SLOOS question whether demand for C\&I loans has changed over the past three months apart from normal seasonal variation. ${ }^{26}$

We estimate a first stage regression in which the dependent variable is a dummy variable that takes the value one if banks indicate they faced weak loan demand and zero otherwise. ${ }^{27}$ If demand factors do not play a role in the loan spreads banks charge riskier borrowers relative to the spreads they charge safer borrowers in periods of low interest rates versus high rates, then we would expect the effect of unobserved demand on loan spreads for riskier borrowers to be insignificant. Finding such evidence would reassure us that firm controls capture loan demand well. This is important for yet another reason. It would show that the SLOOS survey data are a reliable source of information on banks' loan policies as the use of qualitatively different information yields consistent results. ${ }^{28}$

In Table 12, we estimate the same set of models as in Tables 9 and 11. In columns (1) and (2), the estimates on $P D E F A U L T \times D E M A N D_{R E S}$ are insignificant. The differences in these estimates for high- and low-interest-rate regimes are insignificant, which shows up in the insignificant estimate on the triple interaction term in columns (3) and (4). These findings confirm that demand factors are not the key driver of the interest rate discount that riskier

\footnotetext{
${ }^{26}$ The exact survey question is: "Apart from normal seasonal variation, how has demand for C\&I loans changed over the past three months?"

${ }^{27}$ For the sake of comparability, we also rely on the generalized residual from the probit regression that includes macro economic conditions. In an unreported specifications, we have omitted the first stage and directly used the answer to this question in the loan regression. The results continue to hold.

${ }^{28}$ For further information on the effects of lending standards and their quality on bank lending activity see Lown and Morgan (2006).
} 
borrowers enjoy when they take out loans in periods of low short-term interest rates.

In sum, we have presented thus far three important results in support of the existence of a bank risk-taking channel of monetary policy. First, riskier borrowers enjoy an interest rate discount relative to the interest rates safer borrowers pay when they take out loans in periods of low interest rates as opposed to periods of high interest rates. Second, we continue to find evidence of this interest rate discount when we refine our tests to isolate the effect of borrowing in periods of low interest rates from banks with softer lending standards and perhaps even more importantly when we isolate the effect of borrowing in periods of low interest rates from banks with a higher risk tolerance. Third, we show that the interest rate discount is neither demand driven nor arises entirely as a result of the effect of macroeconomic factors.

\section{Final remarks}

While our findings show that the stance of monetary policy is an important driver of banks' risk-taking incentives, it is unclear from our analysis to what extent this effect of monetary policy plays an important role in the stability of the financial system. Nonetheless, our evidence suggests an additional aspect for potential consideration in the design of monetary policy.

Our findings open up several avenues for future research. For instance, our tests focus on banks' loan pricing policies to existing borrowers to reduce concerns with selection. It would be useful to investigate whether the risk-taking incentives brought about by monetary policy also lead banks to change their loan granting policies to new borrowers. Another avenue for future research is understanding what drives the differences of bank and bond issuers risktaking incentives.

Similarly, our tests do not distinguish new loans from renegotiations of existing loans. Mian and Santos (2011), however, show that credit market conditions are an important factor of firms' incentives to refinance their existing credits. Therefore, it would seem useful to investigate the extent to which banks' risk-taking incentives brought about by monetary policy play a role in firms' decisions to refinance and in the terms of their "refinanced" credits. Lastly, our findings suggest that an investigation of the real effects of banks' risk-taking policies induced by monetary policy is also a fruitful area for future research. 


\section{References}

Adrian, T. and Shin, H. (2009). Money, liquidity and monetary policy. American Economic Review, 99:600-605.

Akerlof, G. and Shiller, R. (2009). Animal spirits: How human psychology drives the economy and why it matters for global capitalism. Princeton University Press.

Altunbas, Y., Gambacorta, L., and Marques-Ibanez, D. (2010). Bank risk and monetary policy. Journal of Financial Stability, 6:121-129.

Barakchian, S. and Crowe, C. (2010). Monetary policy matters: New evidence based on a new shock measure. IMF Working Paper, 230.

Bassett, W., Chosak, M., Driscoll, J., and Zakrajšek, E. (2010). Changes in bank lending standards and the macroeconomy. SSRN, 1758832.

Berger, A. and Udell, G. (1990). Collateral, loan quality, and bank risk. Journal of Monetary Economics, 25 (1):21-42.

Bernanke, B. (1983). Nonmonetary effects of the financial crisis in propagation of the great depression. American Economics Review, 73:257-276.

Bernanke, B. and Blinder, A. (1992). The federal funds rate and the channels of monetary transmission. American Economic Review, 82(4):901-921.

Bernanke, B. and Gertler, M. (1995). Inside the black box: The credit channel of monetary policy transmission. Journal of Economic Perspectives, 9:27-48.

Bharath, S. and Shumway, T. (2008). Forecasting default with the merton distance to default model. Review of Financial Studies, 21:1339-1369.

Boot, A., Greenbaum, S., and Thakor, A. (1993). Reputation and discretion in financial contracting. American Economic Review, 83:1165-1183.

Borio, C. and Zhu, H. (2008). Capital regulation, risk-taking and monetary policy: a missing link in the transmission mechanism? BIS Working Papers 268.

Brunnermeier, M. (2009). Deciphering the liquidity and credit crunch 2007-2008. Journal of Economic Perspectives, 23:77-100.

Dell'Ariccia, G. and Marquez, R. (2009). Lending booms and lending standards. Journal of Finance, 61:2511-2546. 
DeYoung, R., Peng, E., and Yan, M. (2012). Executive compensation and business policy choices at us commercial banks. Journal of Financial and Quantitative Analysis, forthcoming.

Diamond, D. and Rajan, R. (2009). Fear of fire sales and the credit freeze. NBER, 14925.

Erel, I., Julio, B., Kim, W., and Weisbach, M. (2012). Macroeconomic conditions and capital raising. Review of Financial Studies, 25:341-376.

Gertler, M. and Gilchrist, S. (1994). Monetary policy, business cycle, and the behavior of small manufacturing firms. Quarterly Journal of Economics, 109:309-340.

Gourieroux, C., Monfort, A., Renault, E., and Trognon, A. (1987). Generalized residuals. Journal of Econometrics, 34:5-32.

Gropp, R., Hakenes, H., and Schnabel, I. (2011). Competition, risk-shifting, and public bail-out policies. Review of Financial Studies, 24:2084-2120.

Hale, G. and Santos, J. (2009). Do banks price their informational monopoly? Journal of Financial Economics, 93:185-206.

Hovakimian, E. and Kane, E. (2000). Effectiveness of capital regulation at u.s. commercial banks, 1985-1994. Journal of Finance, 55:451-469.

Hubbard, R., Kuttner, K., and Palia, D. (2002). Are there bank effects in borrowers' costs of funds? evidence from a matched sample of borrowers and banks. Journal of Business, $75(4): 559-581$.

Ioannidou, V., Ongena, S., and Peydro, J. (2009). Monetary policy, risk-takig and pricing: Evidence from a quasi-natural experiment. CentER Discussion Paper Series 31 S.

Jimenez, G., Saurina, J., Ongena, S., and Peydro, J. (2007). Hazardous times for monetary policy: What do twenty-three million bank loans say about the effects of monetary policy on credit risk-taking? CentER Discussion Paper Series 75.

Kashyap, A. K. and Stein, J. (2000). What do a million observations on banks say about the transmission of monetary policy. American Economic Review, 90:407-428.

Keeley, M. (1990). Deposit insurance, risk, and market power in banking. American Economic Review, 80:1183-2000.

Khwaja, A. I. and Mian, A. (2008). Tracing the impact of bank liquidity shocks: Evidence from an emerging market. American Economic Review, 98 (4):1413-1442. 
Lown, C. and Morgan, D. (2006). The credit cycle and the business: New findings using the loan offer opinion survey. Journal of Money, Credit, and Banking, 38:1576-1597.

Merton, R. (1974). On the pricing of corporate debt: the risk structure of interest rates. Journal of Finance, 2:449-470.

Mian, A. and Santos, J. (2011). Liquidity risk and maturity management over the business cycle. Federal Reserve Bank of New York, mimeo.

Oliner, S. and Rudebisch, G. (1996). Is there a broad credit channel for monetary policy? FRBSF Economic Review, 1:3-13.

Peydro, J. and Maddaloni, A. (2011). Bank risk-taking, securitization, supervision, and low interest rates: Evidence from the euro area and U.S. lending standards. Review of Financial Studies, 24:2121-2165.

Rajan, R. (2006). Has finance made the world riskier? European Financial Management, 12:499-533.

Romer, C. and Romer, D. (2004). A new measure of monetary policy shocks: derivatons and implications. American Economic Review, 94:1055-1084.

Santos, J. (2011). Bank loan pricing following the subprime crisis. Review of Financial Studies, 24:1916-1943.

Santos, J. and Winton, A. (2008). Bank loans, bonds, and informational monopolies across the business cycle. Journal of Finance, 63:1315-1359.

Santos, J. and Winton, A. (2011). Bank capital, borrower power, and loan rates. Federal Reserve Bank of New York, mimeo.

Saunders, A., Strock, E., and Travlos, N. (1990). Ownership structure, deregulation, and bank risk taking. Journal of Finance, 45:643-654.

Schreft, S. and Owens, R. (1991). Survey evidence of tigher credit conditions: What does it mean. Economic Review, March/April:29-34.

Shleifer, A. and Vishny, R. (1997). A survey of corporate governance. Journal of Finance, 52:737-783. 


\section{Appendix 1: Definition of Variables}

$A D V E R T I S I N G$ is advertising expenses scaled by a firm's sales

$B B B S P R E A D$ is the natural log of the difference between the Moody's indexes on the yields of AAA- and BBB-rated bonds

$B G R A D E$ equals one if a borrower has non-investment grade the month before loan origination. The rating is coming from S\&P long-term debt rating at a monthly basis.

$B O N D S P R E A D$ is credit spreads over the Treasury with the same maturity as that of the bond

$C A L L A B L E$ is an indicator variable that takes one is a bond is callable

$C A P I T A L B K$ is the ratio of equity over risk-weighted assets

CONVIRTIBLE is an indicator variable that takes one is a bond is convertible.

$C H A R G E O F F S B K$ is net charge off over risk weighted assets

CORP PURPOSES is one if the loan is for corporate purpose.

CREDIT LINE equals one if the loan is a credit line.

$D E B T$ REPAY is one if the loan is for repayment of previous debt.

$D E C R E A S I N G$ is an indicator variable that takes one if the fed funds rate is lower compared to the previous quarter.

$D E M A N D W E A K$ is equal to one in the quarters a bank indicates that C\&I loan demand was weak for reasons other than seasonal changes.

DEPOSITS BK is the ratio of deposits over assets.

$D I V$ RESTRICT is equal to one if the borrower has to meet a dividend restriction.

FLOATING is an indicator variable that takes one is a bond has a variable coupon

$E A S I N G$ is equal to one in the quarters a bank indicates that its standards are easier than in the previous three months.

$E X R E T$ is the one year stock return over the market return.

$L A G E$ is the natural log of a firm's age (in years). 
$L A S S E T S B K$ is the natural log of bank assets at the quarter before loan was originated.

$L A M O U N T$ is the natural log of loan amount in hundreds of millions of dollars.

$L E A D S H A R E$ is the portion of facility kept by the lead arranger

$L E V E R A G E$ is debt over total assets.

L INTCOV is the natural log of one plus EBITDA over interest expense.

LIQUIDITY BK is liquidity over risk-weighted assets.

$L L O A N S P D$ is the natural log of the all-in-drawn loan spread over LIBOR (in basis points) at origination.

$L M A T U R I T Y$ is the natural log of the maturity of the loan in years.

$L O W R A T E$ is an indicator variable that takes one if the federal funds rate is lower than the sample median.

$L S A L E S$ is the natural $\log$ of the firm's annual sales in hundred millions of US dollars.

$M K T B O O K$ is the ratio of market to book value of the firm.

$N W C$ is net working capital over debt.

$P D E F A U L T$ is the probability of default defined as the cumulative normal distribution of distance-to-default measure proposed by Bharath and Shumway (2008).

PRIVATE indicated whether the bond is placed privately.

PROF MARGIN is the ratio of net income over sales.

$R \& D$ is research and development expenses scaled by a firm's sales.

RISK TOL is equal to one in the quarters a bank indicates its lending standards are easier and that "increased tolerance for risk" was very important or somewhat important for easing the terms for C\&I loans.

$R O A B K$ is the bank's net income before taxes over risk weighted assets.

ROA VOL BK is the volatility of the bank's return on assets.

ROMER SHOCK is a dummy variable that takes one for negative values of the residuals retrieved from a regression of intended federal funds rate on the Federal Reserve's internal forecast of inflation and real activity. 
$S E C U R E D$ is equal to one if the loan is secured.

$S L O P E Y C$ is the difference between the yields of the five and one year zero coupon bond. STOCK VOL is the one year stock return volatility using daily returns.

$S U B D E T B K$ is the fraction of the bank's subordinated debt to total assets.

$T A N G I B L E S$ is inventories plus plant, property, and equipment over total assets

TAYLOR SHOCK is a dummy variable that takes on if the deviation of the actual funds rates from the Taylor-rule predicted funds rate is negative. The rule is based on inflation and unemployment net of the Congressional Budget Office natural unemployment rate.

TERMLOAN is equal to one if a loan is a term loan.

$U N R A T E D$ is equal to one for borrowers that do not have a credit rating.

WORK CAPITAL is one if the loan is for working capital. 
Figure 1: Federal Funds (Target) Rate

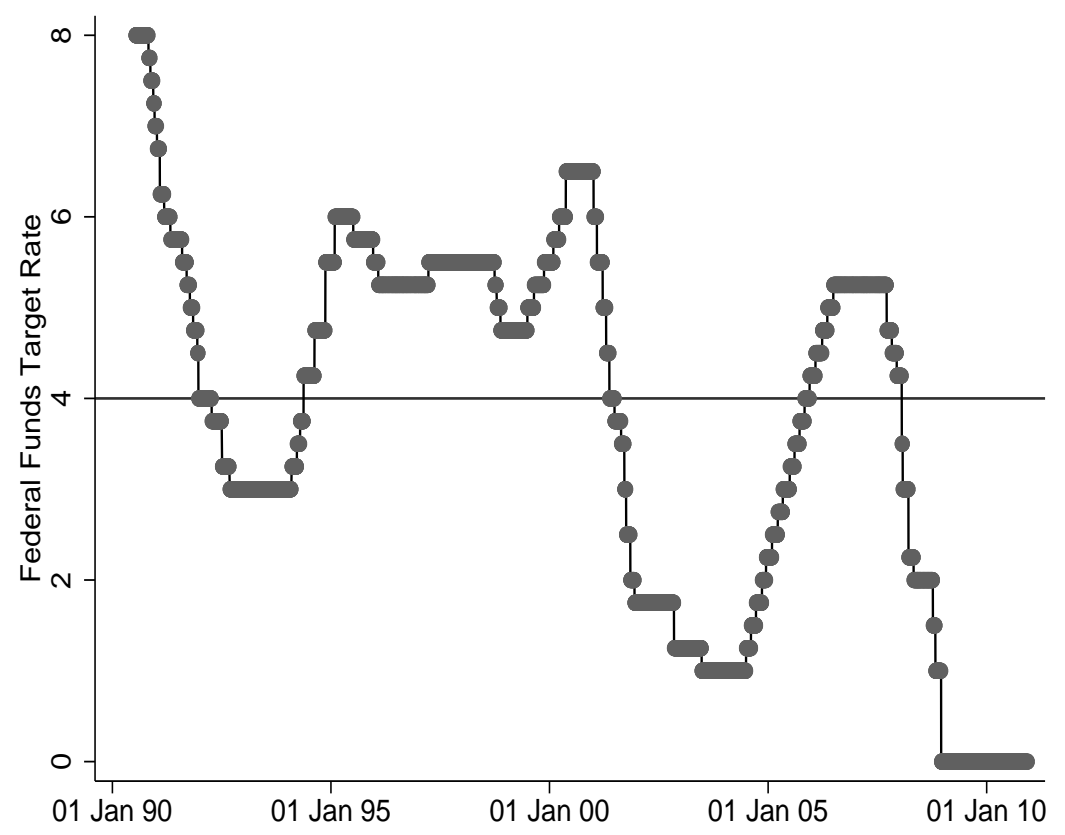

Note: This graph shows federal funds target rate at the daily level as determined by the members of the Federal Open Market Committee. The rates below the horizontal line are classified as a low rate regime and above it as a high rate regime. The downward/upward sloping parts of the graph are periods of decreasing/increasing rates. 
Table 1: SAMPLE CHARACTERISTICS

\begin{tabular}{|c|c|c|c|c|c|}
\hline & MEAN & ST.DEV & 25 th & MEDIAN & 75 th \\
\hline & \multicolumn{5}{|c|}{ FIRM CONTROLS } \\
\hline AGE & 19.576 & 16.414 & 6.000 & 13.000 & 31.000 \\
\hline SALES (million \$) & 4069 & 14899 & 183.3 & 722 & 2748.2 \\
\hline LEVERAGE & 0.324 & 0.244 & 0.147 & 0.299 & 0.444 \\
\hline TANGIBILITY & 0.727 & 0.377 & 0.445 & 0.714 & 0.983 \\
\hline $\mathrm{RD}$ & 0.045 & 0.561 & 0.000 & 0.000 & 0.012 \\
\hline ADVERTISING & 0.011 & 0.037 & 0.000 & 0.000 & 0.006 \\
\hline L INTCOV & 1.914 & 1.242 & 1.196 & 1.769 & 2.471 \\
\hline MKTBOOK & 1.744 & 1.027 & 1.112 & 1.409 & 1.978 \\
\hline PROF MARGIN & -0.045 & 0.642 & -0.006 & 0.032 & 0.072 \\
\hline NWC & 6.074 & 23.474 & 0.031 & 0.428 & 1.468 \\
\hline EX RET & 0.093 & 0.499 & -0.172 & 0.058 & 0.328 \\
\hline STOCK VOL & 0.033 & 0.019 & 0.020 & 0.028 & 0.041 \\
\hline P DEFAULT & 0.040 & 0.111 & 0.000 & 0.000 & 0.005 \\
\hline RATED & 0.437 & 0.496 & 0.000 & 0.000 & 1.000 \\
\hline I GRADE & 0.237 & 0.426 & 0.000 & 0.000 & 0.000 \\
\hline \multirow[t]{2}{*}{ B GRADE } & 0.199 & 0.399 & 0.000 & 0.000 & 0.000 \\
\hline & \multicolumn{5}{|c|}{ LOAN CONTROLS } \\
\hline AMOUNT (million \$) & 204.282 & 560.664 & 20.000 & 64.000 & 190.000 \\
\hline LOAN SPD (bsp) & 247.147 & 153.836 & 144.000 & 250.000 & 325.000 \\
\hline MATURITY (years) & 4.000 & 2.290 & 2.000 & 4.000 & 5.000 \\
\hline CREDIT LINE & 0.543 & 0.498 & 0.000 & 1.000 & 1.000 \\
\hline TERM LOAN & 0.284 & 0.451 & 0.000 & 0.000 & 1.000 \\
\hline CORP PURPOSES & 0.340 & 0.474 & 0.000 & 0.000 & 1.000 \\
\hline WORK CAPITAL & 0.112 & 0.315 & 0.000 & 0.000 & 0.000 \\
\hline DEBT REPAY & 0.117 & 0.321 & 0.000 & 0.000 & 0.000 \\
\hline SECURED & 0.924 & 0.265 & 1.000 & 1.000 & 1.000 \\
\hline DIV RESTRICT & 0.851 & 0.356 & 1.000 & 1.000 & 1.000 \\
\hline \multirow[t]{2}{*}{ LEAD SHARE } & 0.421 & 0.376 & 0.113 & 0.250 & 1.00 \\
\hline & \multicolumn{5}{|c|}{ BOND CONTROLS } \\
\hline AMOUNT (million \$) & 271.000 & 920.000 & 50.000 & 164.000 & 300.000 \\
\hline BOND SPREAD (bsp) & 136.000 & 220 & 7.397 & 92.491 & 244.000 \\
\hline BOND MATURITY(years) & 10.971 & 9.238 & 5.000 & 9.000 & 10.000 \\
\hline CALLABLE & 0.090 & 0.281 & 0.000 & 0.000 & 0.000 \\
\hline CONVERTIBLE & 0.118 & 0.324 & 0.000 & 0.000 & 1.000 \\
\hline PRIVATE & 0.191 & 0.393 & 0.000 & 0.000 & 0.000 \\
\hline \multirow[t]{2}{*}{ FLOATING } & 0.062 & 0.242 & 0.000 & 0.000 & 0.000 \\
\hline & \multicolumn{5}{|c|}{ BANK CONTROLS } \\
\hline ASSETS BK (billion \$) & 584.187 & 626.16 & 90.801 & 272.426 & 1083.31 \\
\hline CAPITAL BK & 8.261 & 2.435 & 6.898 & 7.998 & 9.372 \\
\hline DEPOSITS BK & 0.653 & 0.182 & 0.576 & 0.675 & 0.779 \\
\hline SUBDEBT BK & 0.014 & 0.013 & 0.000 & 0.013 & 0.024 \\
\hline LIQUIDITY BK & 0.244 & 0.094 & 0.178 & 0.235 & 0.303 \\
\hline ROA BK & 0.001 & 0.001 & 0.001 & 0.001 & 0.002 \\
\hline ROA VOL BK & 0.002 & 0.002 & 0.000 & 0.001 & 0.002 \\
\hline CHARGEOFFS BK & 0.001 & 0.001 & 0.000 & 0.001 & 0.001 \\
\hline AAA BK & 0.018 & 0.132 & 0.000 & 0.000 & 0.000 \\
\hline AA BK & 0.242 & 0.428 & 0.000 & 0.000 & 0.000 \\
\hline A BK & 0.432 & 0.496 & 0.000 & 0.000 & 1.000 \\
\hline BBB BK & 0.029 & 0.168 & 0.000 & 0.000 & 0.000 \\
\hline BELOW BBB BK & 0.001 & 0.035 & 0.000 & 0.000 & 0.000 \\
\hline UNRATED BK & 0.279 & 0.448 & 0.000 & 0.000 & 1.000 \\
\hline EASING & 0.068 & 0.253 & 0.000 & 0.000 & 0.000 \\
\hline RISK TOL & 0.047 & 0.212 & 0.000 & 0.000 & 0.000 \\
\hline \multirow[t]{2}{*}{ DEMAND WEAK } & 0.280 & 0.499 & 0.000 & 0.000 & 1.000 \\
\hline & \multicolumn{5}{|c|}{ MACRO CONTROLS } \\
\hline BBB SPREAD & 1.882 & 0.196 & 1.737 & 1.907 & 2.014 \\
\hline SLOPE YC & 0.836 & 0.832 & 0.103 & 0.681 & 1.581 \\
\hline
\end{tabular}


Table 2: LOAN SPREADS: FIRST RESULTS

The dependent variable is L LOANSPD, the log of the all-in-drawn spread over LIBOR at origination. All variables are defined in Appendix 2. All models include year, quarter, and bank/bank-firm fixed effects. Standard errors are clustered at the bank level. ${ }^{* * *}$ denotes $1 \%$ significant level, $* *$ denotes $5 \%$ significant level, and * denotes $10 \%$ significant level.

\begin{tabular}{|c|c|c|c|c|c|c|}
\hline & (1) & $(2)$ & $(3)$ & $(4)$ & $(5)$ & $(6)$ \\
\hline \multirow{2}{*}{ LOW RATE } & $0.120^{* * *}$ & $0.121^{* * *}$ & $0.098^{* * *}$ & $0.089^{* * *}$ & $0.080^{* * *}$ & $0.086^{* * *}$ \\
\hline & $(0.024)$ & $(0.018)$ & $(0.020)$ & $(0.025)$ & $(0.018)$ & $(0.022)$ \\
\hline \multirow[t]{2}{*}{ B GRADE } & $0.824^{* * *}$ & $0.698^{* * *}$ & $0.385^{* * *}$ & & & \\
\hline & $(0.054)$ & $(0.053)$ & $(0.054)$ & & & \\
\hline \multirow[t]{2}{*}{ UNRATED } & $0.549 * * *$ & $0.448^{* * *}$ & $0.314^{* * *}$ & & & \\
\hline & $(0.046)$ & $(0.047)$ & $(0.068)$ & & & \\
\hline \multirow[t]{2}{*}{$P D E F A U L T$} & & & & $1.254^{* * *}$ & $0.971^{* * *}$ & $0.723^{* * *}$ \\
\hline & & & & $(0.123)$ & $(0.087)$ & $(0.068)$ \\
\hline \multirow[t]{2}{*}{ L AGE } & $-0.083^{* * *}$ & $-0.080^{* * *}$ & $-0.203^{* * *}$ & $-0.205^{* * *}$ & $-0.165^{* * *}$ & $-0.202^{* * *}$ \\
\hline & $(0.014)$ & $(0.012)$ & $(0.041)$ & $(0.027)$ & $(0.018)$ & $(0.034)$ \\
\hline \multirow[t]{2}{*}{ L SALES } & $-0.136^{* * *}$ & $-0.087^{* * *}$ & $-0.116^{* * *}$ & $-0.203^{* * *}$ & $-0.122^{* * *}$ & $-0.140^{* * *}$ \\
\hline & $(0.008)$ & $(0.008)$ & $(0.012)$ & $(0.004)$ & $(0.007)$ & $(0.012)$ \\
\hline \multirow[t]{2}{*}{ LEVERAGE } & $0.255^{* * *}$ & $0.218^{* * *}$ & $0.332^{* * *}$ & & & \\
\hline & $(0.030)$ & $(0.026)$ & $(0.043)$ & & & \\
\hline \multirow[t]{2}{*}{ TANGIBLES } & $-0.110^{* * *}$ & $-0.077^{* * *}$ & $-0.100 * *$ & $-0.137^{* * *}$ & $-0.090 * * *$ & -0.035 \\
\hline & $(0.023)$ & $(0.019)$ & $(0.043)$ & $(0.022)$ & $(0.020)$ & $(0.038)$ \\
\hline \multirow[t]{2}{*}{ R\&D } & $-0.651^{* * *}$ & $-0.606^{* *}$ & -0.496 & $-0.747^{* *}$ & $-0.638^{* *}$ & -0.557 \\
\hline & $(0.228)$ & $(0.237)$ & $(0.409)$ & $(0.290)$ & $(0.289)$ & $(0.402)$ \\
\hline \multirow[t]{2}{*}{ ADVERTISING } & $-0.800 * * *$ & $-0.741^{* *}$ & $-0.899^{* *}$ & -0.453 & -0.383 & -0.601 \\
\hline & $(0.287)$ & $(0.292)$ & $(0.384)$ & $(0.288)$ & $(0.290)$ & $(0.532)$ \\
\hline \multirow[t]{2}{*}{ L INTCOV } & $-0.081^{* * *}$ & $-0.073^{* * *}$ & $-0.051^{* * *}$ & $-0.130^{* * *}$ & $-0.108^{* * *}$ & $-0.080^{* * *}$ \\
\hline & $(0.007)$ & $(0.008)$ & $(0.010)$ & $(0.016)$ & $(0.013)$ & $(0.013)$ \\
\hline \multirow[t]{2}{*}{ MKTBOOK } & $-0.110^{* * *}$ & $-0.101^{* * *}$ & $-0.077^{*} * *$ & $-0.146^{* * *}$ & $-0.120^{* * *}$ & $-0.101^{* * *}$ \\
\hline & $(0.014)$ & $(0.012)$ & $(0.011)$ & $(0.015)$ & $(0.014)$ & $(0.011)$ \\
\hline \multirow[t]{2}{*}{ PROF MARGIN } & $0.074^{* * *}$ & $0.062^{* * *}$ & $0.055^{* *}$ & $0.067 * * *$ & $0.059^{* * *}$ & $0.053^{* *}$ \\
\hline & $(0.014)$ & $(0.011)$ & $(0.024)$ & $(0.023)$ & $(0.014)$ & $(0.027)$ \\
\hline \multirow[t]{2}{*}{ NWC } & -0.000 & 0.000 & 0.000 & $0.001^{*}$ & $0.001^{* *}$ & $0.000^{*}$ \\
\hline & $(0.000)$ & $(0.000)$ & $(0.000)$ & $(0.000)$ & $(0.000)$ & $(0.000)$ \\
\hline \multirow[t]{2}{*}{ EX RET } & $-0.061^{* * *}$ & $-0.045^{* * *}$ & $-0.068^{* * *}$ & & & \\
\hline & $(0.013)$ & $(0.010)$ & $(0.012)$ & & & \\
\hline \multirow[t]{2}{*}{ STOCK VOL } & $8.808^{* * *}$ & $7.160 * * *$ & $3.932 * * *$ & & & \\
\hline & $(0.743)$ & $(0.687)$ & $(0.433)$ & & & \\
\hline \multirow[t]{2}{*}{ L AMOUNT } & & $-0.070^{* * *}$ & $-0.034^{* * *}$ & & $-0.077^{* * *}$ & $-0.032^{* * *}$ \\
\hline & & $(0.005)$ & $(0.005)$ & & $(0.006)$ & $(0.005)$ \\
\hline \multirow[t]{2}{*}{ L MATURITY } & & $-0.011^{*}$ & -0.004 & & 0.003 & $-0.005^{* *}$ \\
\hline & & $(0.006)$ & $(0.003)$ & & $(0.007)$ & $(0.003)$ \\
\hline \multirow[t]{2}{*}{ SECURED } & & $0.175^{* * *}$ & $0.119^{* * *}$ & & $0.310^{* * *}$ & $0.134^{* * *}$ \\
\hline & & $(0.021)$ & $(0.012)$ & & $(0.017)$ & $(0.011)$ \\
\hline \multirow[t]{2}{*}{ CREDIT LINE } & & $-0.314^{* * *}$ & $-0.242^{* * *}$ & & $-0.411^{* * *}$ & $-0.267^{* * *}$ \\
\hline & & $(0.046)$ & $(0.035)$ & & $(0.065)$ & $(0.031)$ \\
\hline \multirow[t]{2}{*}{ TERM LOAN } & & $-0.067^{*}$ & $-0.111^{* * *}$ & & $-0.108^{* *}$ & $-0.124^{* * *}$ \\
\hline & & $(0.039)$ & $(0.037)$ & & $(0.045)$ & $(0.033)$ \\
\hline \multirow[t]{2}{*}{ DIV RESRICT } & & $0.195^{* * *}$ & $0.107^{* * *}$ & & $0.297^{* * *}$ & $0.127^{* * *}$ \\
\hline & & $(0.019)$ & $(0.016)$ & & $(0.034)$ & $(0.017)$ \\
\hline CORP PURPOSES & & -0.007 & $-0.030^{* *}$ & & 0.009 & -0.021 \\
\hline & & $(0.019)$ & $(0.015)$ & & $(0.022)$ & $(0.017)$ \\
\hline
\end{tabular}




\begin{tabular}{|c|c|c|c|c|c|c|}
\hline DEBT REPAY & & $\begin{array}{l}-0.021 \\
(0.014)\end{array}$ & $\begin{array}{l}-0.037^{* *} \\
(0.017)\end{array}$ & & $\begin{array}{l}0.020 \\
(0.016)\end{array}$ & $\begin{array}{l}-0.015 \\
(0.018)\end{array}$ \\
\hline WORK CAPITAL & & $\begin{array}{l}-0.015 \\
(0.020)\end{array}$ & $\begin{array}{l}-0.052^{* * *} \\
(0.020)\end{array}$ & & $\begin{array}{l}0.018 \\
(0.024)\end{array}$ & $\begin{array}{l}-0.056^{* * *} \\
(0.017)\end{array}$ \\
\hline L ASSETS BK & $\begin{array}{l}-0.047 \\
(0.049)\end{array}$ & $\begin{array}{l}-0.039 \\
(0.049)\end{array}$ & $\begin{array}{l}-0.013 \\
(0.071)\end{array}$ & $\begin{array}{l}-0.046 \\
(0.045)\end{array}$ & $\begin{array}{l}-0.031 \\
(0.045)\end{array}$ & $\begin{array}{l}-0.025 \\
(0.072)\end{array}$ \\
\hline ROA BK & $\begin{array}{l}-2.000 \\
(6.579)\end{array}$ & $\begin{array}{l}1.563 \\
(7.006)\end{array}$ & $\begin{array}{l}-3.453 \\
(10.722)\end{array}$ & $\begin{array}{l}-3.683 \\
(9.052)\end{array}$ & $\begin{array}{l}-0.045 \\
(9.524)\end{array}$ & $\begin{array}{l}-0.971 \\
(12.452)\end{array}$ \\
\hline SUBDEBT BK & $\begin{array}{l}0.361 \\
(1.767)\end{array}$ & $\begin{array}{l}0.604 \\
(1.499)\end{array}$ & $\begin{array}{l}1.316 \\
(1.599)\end{array}$ & $\begin{array}{l}0.089 \\
(2.019)\end{array}$ & $\begin{array}{l}0.469 \\
(1.731)\end{array}$ & $\begin{array}{l}-0.534 \\
(1.545)\end{array}$ \\
\hline ROA VOL BK & $\begin{array}{l}-18.709^{* *} \\
(8.303)\end{array}$ & $\begin{array}{l}-14.239^{* *} \\
(7.207)\end{array}$ & $\begin{array}{l}-0.538 \\
(8.769)\end{array}$ & $\begin{array}{c}-13.894 \\
(8.625)\end{array}$ & $\begin{array}{l}-10.250 \\
(6.911)\end{array}$ & $\begin{array}{l}-0.987 \\
(8.121)\end{array}$ \\
\hline CHARGEOFFS BK & $\begin{array}{l}18.911^{* *} \\
(8.731)\end{array}$ & $\begin{array}{l}18.067^{* *} \\
(8.508)\end{array}$ & $\begin{array}{l}17.823 \\
(11.488)\end{array}$ & $\begin{array}{l}20.292^{* *} \\
(7.858)\end{array}$ & $\begin{array}{l}17.355^{* *} \\
(7.260)\end{array}$ & $\begin{array}{l}12.030 \\
(11.269)\end{array}$ \\
\hline LIQUIDITY BK & $\begin{array}{l}-0.006 \\
(0.209)\end{array}$ & $\begin{array}{l}-0.058 \\
(0.196)\end{array}$ & $\begin{array}{l}0.260 \\
(0.166)\end{array}$ & $\begin{array}{l}-0.161 \\
(0.222)\end{array}$ & $\begin{array}{l}-0.133 \\
(0.209)\end{array}$ & $\begin{array}{l}0.111 \\
(0.188)\end{array}$ \\
\hline CAPITAL BK & $\begin{array}{l}-0.013^{*} \\
(0.007)\end{array}$ & $\begin{array}{l}-0.013^{* *} \\
(0.007)\end{array}$ & $\begin{array}{l}-0.006 \\
(0.007)\end{array}$ & $\begin{array}{l}-0.009 \\
(0.006)\end{array}$ & $\begin{array}{l}-0.012^{* *} \\
(0.005)\end{array}$ & $\begin{array}{l}-0.008 \\
(0.008)\end{array}$ \\
\hline DEPOSITS BK & $\begin{array}{l}0.160 \\
(0.121)\end{array}$ & $\begin{array}{l}0.144 \\
(0.118)\end{array}$ & $\begin{array}{l}0.263^{* *} \\
(0.103)\end{array}$ & $\begin{array}{l}0.198^{*} \\
(0.112)\end{array}$ & $\begin{array}{l}0.153 \\
(0.110)\end{array}$ & $\begin{array}{l}0.197^{*} \\
(0.117)\end{array}$ \\
\hline AA BK & $\begin{array}{l}-0.178^{* *} \\
(0.072)\end{array}$ & $\begin{array}{l}-0.199^{* * *} \\
(0.070)\end{array}$ & $\begin{array}{l}-0.021 \\
(0.086)\end{array}$ & $\begin{array}{l}-0.052 \\
(0.066)\end{array}$ & $\begin{array}{l}-0.077 \\
(0.065)\end{array}$ & $\begin{array}{l}-0.101 \\
(0.082)\end{array}$ \\
\hline A BK & $\begin{array}{l}-0.208^{* * *} \\
(0.067)\end{array}$ & $\begin{array}{l}-0.235^{* * *} \\
(0.063)\end{array}$ & $\begin{array}{l}-0.032 \\
(0.084)\end{array}$ & $\begin{array}{l}-0.086 \\
(0.063)\end{array}$ & $\begin{array}{l}-0.118^{*} \\
(0.062)\end{array}$ & $\begin{array}{l}-0.096 \\
(0.079)\end{array}$ \\
\hline BBB BK & $\begin{array}{l}-0.171^{*} \\
(0.095)\end{array}$ & $\begin{array}{l}-0.206^{* *} \\
(0.092)\end{array}$ & $\begin{array}{l}-0.014 \\
(0.107)\end{array}$ & $\begin{array}{l}-0.006 \\
(0.092)\end{array}$ & $\begin{array}{l}-0.063 \\
(0.089)\end{array}$ & $\begin{array}{l}0.002 \\
(0.090)\end{array}$ \\
\hline BELOW BBB BK & $\begin{array}{l}-0.029 \\
(0.179)\end{array}$ & $\begin{array}{l}-0.031 \\
(0.159)\end{array}$ & $\begin{array}{l}-0.062 \\
(0.077)\end{array}$ & $\begin{array}{l}0.077 \\
(0.182)\end{array}$ & $\begin{array}{l}0.075 \\
(0.172)\end{array}$ & $\begin{array}{l}-0.266 \\
(0.170)\end{array}$ \\
\hline UNRATED BK & $\begin{array}{l}-0.103 \\
(0.096)\end{array}$ & $\begin{array}{l}-0.118 \\
(0.087)\end{array}$ & $\begin{array}{c}-0.170^{*} \\
(0.096)\end{array}$ & $\begin{array}{l}0.087 \\
(0.102)\end{array}$ & $\begin{array}{l}0.043 \\
(0.091)\end{array}$ & $\begin{array}{l}-0.209^{* *} \\
(0.093)\end{array}$ \\
\hline BBB SPREAD & $\begin{array}{l}0.407^{* * * *} \\
(0.072)\end{array}$ & $\begin{array}{l}0.297^{* * * *} \\
(0.065)\end{array}$ & $\begin{array}{l}0.453^{* * *} \\
(0.059)\end{array}$ & $\begin{array}{l}0.278^{* * *} \\
(0.096)\end{array}$ & $\begin{array}{l}0.176^{* *} \\
(0.083)\end{array}$ & $\begin{array}{l}0.376^{* * *} \\
(0.076)\end{array}$ \\
\hline SLOPE YC & $\begin{array}{l}-0.000 \\
(0.009)\end{array}$ & $\begin{array}{l}0.002 \\
(0.010)\end{array}$ & $\begin{array}{l}0.019 \\
(0.012)\end{array}$ & $\begin{array}{l}0.000 \\
(0.009)\end{array}$ & $\begin{array}{l}0.020^{*} \\
(0.011)\end{array}$ & $\begin{array}{l}0.030^{* *} \\
(0.014)\end{array}$ \\
\hline Year & Yes & Yes & Yes & Yes & Yes & Yes \\
\hline Quarter & Yes & Yes & Yes & Yes & Yes & Yes \\
\hline Bank FE & Yes & Yes & & Yes & Yes & \\
\hline Bank-Firm FE & & & Yes & & & Yes \\
\hline$R^{2}$ & 0.592 & 0.629 & 0.408 & 0.466 & 0.553 & 0.377 \\
\hline Observations & 18,787 & 17,498 & 17,498 & 19,380 & 18,169 & 18,169 \\
\hline
\end{tabular}


Table 3: LOAN SPREADS AND INTERACTIONS: BASE RESULTS

The dependent variable is L LOAN SPD, the log of the all-in-drawn spread over LIBOR at origination. All variables are defined in Appendix 2. All models include year, quarter, and bank/bank-firm fixed effects. Standard errors are clustered at the bank level. *** denotes $1 \%$ significant level, ${ }^{* *}$ denotes $5 \%$ significant level, and * denotes $10 \%$ significant level.

\begin{tabular}{|c|c|c|c|c|c|c|}
\hline & $(1)$ & $(2)$ & $(3)$ & $(4)$ & $(5)$ & $(6)$ \\
\hline$L O W R A T E \times \mathrm{B}$ GRADE & $\begin{array}{l}-0.134^{* * *} \\
(0.034)\end{array}$ & $\begin{array}{l}-0.146^{* * *} \\
(0.027)\end{array}$ & $\begin{array}{l}-0.055^{* *} \\
(0.021)\end{array}$ & & & \\
\hline$L O W R A T E \times$ UNRATED & $\begin{array}{l}-0.170^{* * *} \\
(0.034)\end{array}$ & $\begin{array}{l}-0.180^{* * * *} \\
(0.029)\end{array}$ & $\begin{array}{l}-0.098^{* * * *} \\
(0.015)\end{array}$ & & & \\
\hline$L O W R A T E$ & $\begin{array}{l}0.229 * * * \\
(0.038)\end{array}$ & $\begin{array}{l}0.239 * * * \\
(0.029)\end{array}$ & $\begin{array}{l}0.146^{* * *} \\
(0.027)\end{array}$ & $\begin{array}{l}0.091^{* * *} \\
(0.028)\end{array}$ & $\begin{array}{l}0.086^{* * *} \\
(0.019)\end{array}$ & $\begin{array}{l}0.099 * * * \\
(0.023)\end{array}$ \\
\hline B GRADE & $\begin{array}{l}0.897^{* * *} \\
(0.059)\end{array}$ & $\begin{array}{l}0.775^{* * *} \\
(0.056)\end{array}$ & $\begin{array}{l}0.408^{* * *} \\
(0.049)\end{array}$ & & & \\
\hline UNRATED & $\begin{array}{l}0.634^{* * *} \\
(0.056)\end{array}$ & $\begin{array}{l}0.538^{* * *} \\
(0.056)\end{array}$ & $\begin{array}{l}0.352^{* * *} \\
(0.069)\end{array}$ & & & \\
\hline$P D E F A U L T$ & & & & $\begin{array}{l}1.290^{* * *} \\
(0.154)\end{array}$ & $\begin{array}{l}1.057^{* * *} \\
(0.126)\end{array}$ & $\begin{array}{l}1.065^{* * *} \\
(0.117)\end{array}$ \\
\hline$L O W R A T E \times P$ DEF AULT & & & & $\begin{array}{l}-0.060 \\
(0.131)\end{array}$ & $\begin{array}{l}-0.146^{*} \\
(0.089)\end{array}$ & $\begin{array}{l}-0.504^{* * *} \\
(0.093)\end{array}$ \\
\hline Loan Controls & & Yes & Yes & & Yes & Yes \\
\hline Firm Controls & Yes & Yes & Yes & Yes & Yes & Yes \\
\hline Bank Controls & Yes & Yes & Yes & Yes & Yes & Yes \\
\hline Macro Controls & Yes & Yes & Yes & Yes & Yes & Yes \\
\hline Year & Yes & Yes & Yes & Yes & Yes & Yes \\
\hline Quarter & Yes & Yes & Yes & Yes & Yes & Yes \\
\hline Bank FE & Yes & Yes & & Yes & Yes & \\
\hline Bank-Firm FE & & & Yes & & & Yes \\
\hline$R^{2}$ & 0.594 & 0.631 & 0.409 & 0.461 & 0.553 & 0.378 \\
\hline Observations & 18,787 & 17,498 & 17,498 & 19,380 & 18,169 & 18,169 \\
\hline
\end{tabular}


Table 4: LOAN AMOUNTS

The dependent variable is L AMOUNT. We include a new control LEAD SHARE that is fraction of facility held by lead arrangers. All variables are defined in Appendix 2. *** denotes $1 \%$ significant level, $* *$ denotes $5 \%$ significant level, and * denotes $10 \%$ significant level.

\begin{tabular}{lllll}
\hline & $(1)$ & $(2)$ & $(3)$ & $(4)$ \\
\hline LOW RATE $\times$ BGRADE & $0.171^{* * *}$ & $0.057^{* *}$ & & \\
LOW RATE $\times$ UNRATED & $(0.029)$ & $(0.027)$ & & \\
& $0.070^{* *}$ & 0.007 & & -0.027 \\
LOW RATE & $(0.027)$ & $(0.029)$ & & $(0.091)$ \\
& -0.051 & 0.017 & 0.024 & \\
BGRADE & $(0.033)$ & $(0.028)$ & $(0.032)$ & \\
& -0.025 & -0.049 & & \\
UNRATED & $(0.027)$ & $(0.045)$ & & $-0.339^{* * *}$ \\
P DEFAULT & $-0.290^{* * *}$ & -0.022 & & $(0.127)$ \\
& $(0.039)$ & $(0.056)$ & & $0.330^{* *}$ \\
LOW RATE $\times \mathrm{P}$ DEFAULT & & & $-0.708^{* * *}$ & $(0.155)$ \\
& & & $(0.115)$ & Yes \\
Loan Controls & & & $0.297^{* * *}$ & $(0.103)$ \\
Firms Controls & Yes & Yes & Yes & Yes \\
Bank Controls & Yes & Yes & Yes & Yes \\
Year & Yes & Yes & Yes & Yes \\
Quarter & Yes & Yes & Yes & Yes \\
Bank FE & Yes & Yes & Yes & \\
Bank-Firm FE & Yes & & & 18,169 \\
$R^{2}$ & & Yes & & \\
Observations & 0.638 & 0.169 & 0.621 & 18,169 \\
\hline
\end{tabular}


Table 5: DEMAND FOR LOANS

The dependent variable is L LOAN SPD. All variables are defined in Appendix 2. In columns (1) and (2) firm-time and bank-firm-time fixed effects are included. Time denotes a three-year period. In columns (3)-(6) the sample is split into large firms (sales higher than the sample median) and small firms (sales lower than the sample median). *** denotes $1 \%$ significant level, $* *$ denotes $5 \%$ significant level, and * denotes $10 \%$ significant level.

\begin{tabular}{|c|c|c|c|c|c|c|}
\hline & (1) & (2) & $\begin{array}{l}\text { Large Firms } \\
\text { (3) }\end{array}$ & $\begin{array}{l}\text { Small Firms } \\
\text { (4) }\end{array}$ & $\begin{array}{l}\text { Large Firms } \\
\text { (5) }\end{array}$ & $\begin{array}{l}\text { Small Firms } \\
(6)\end{array}$ \\
\hline \multirow[t]{2}{*}{$\mathrm{P}$ DEFAULT } & $0.922^{* * *}$ & $0.957^{* * *}$ & $1.566^{* * *}$ & $0.952^{* * *}$ & $1.160^{* * *}$ & $0.780 * * *$ \\
\hline & $(0.119)$ & $(0.088)$ & $(0.252)$ & $(0.103)$ & $(0.178)$ & $(0.146)$ \\
\hline \multirow[t]{2}{*}{ LOW RATE $\times$ P DEFAULT } & $-0.292^{* *}$ & $-0.365^{* * *}$ & $-0.793^{* * *}$ & $-0.256^{* * *}$ & $-0.690^{* * *}$ & $-0.283^{* *}$ \\
\hline & $(0.142)$ & $(0.092)$ & $(0.244)$ & $(0.087)$ & $(0.136)$ & $(0.111)$ \\
\hline \multirow[t]{2}{*}{ LOW RATE } & $0.111^{* * *}$ & $0.094^{* * *}$ & $0.111^{* * *}$ & $0.059^{* *}$ & $0.102^{* * *}$ & $0.056^{*}$ \\
\hline & $(0.023)$ & $(0.012)$ & $(0.026)$ & $(0.027)$ & $(0.029)$ & $(0.030)$ \\
\hline Loan Controls & Yes & Yes & Yes & Yes & Yes & Yes \\
\hline Firms Controls & Yes & Yes & Yes & Yes & Yes & Yes \\
\hline Bank Controls & Yes & Yes & Yes & Yes & Yes & Yes \\
\hline Macro Controls & Yes & Yes & Yes & Yes & Yes & Yes \\
\hline Year & Yes & Yes & Yes & Yes & Yes & Yes \\
\hline Quarter & Yes & Yes & Yes & Yes & Yes & Yes \\
\hline Bank FE & & & Yes & Yes & & \\
\hline Bank-Firm FE & & & & & Yes & Yes \\
\hline Firm-Time & Yes & & & & & \\
\hline Firm-Bank-Time FE & & Yes & & & & \\
\hline$R^{2}$ & 0.228 & 0.211 & 0.628 & 0.373 & 0.466 & 0.235 \\
\hline Observations & 9,083 & 9,083 & 9,367 & 8,802 & 9367 & 8,802 \\
\hline
\end{tabular}


Table 6: BOND SPREADS AND RISK-TAKING

The dependent variable is BOND SPREAD. Macro Controls include the slope of the yield curve $(S L O P E Y C)$. All firm (issuer) and issue controls are described in Appendix 2. In columns (3) and (4) we omit issues that are convertible, callable, and with a floating coupon. In columns (5) and (6) we omit public placements. $* * *$ denotes $1 \%$ significant level, ${ }^{* *}$ denotes $5 \%$ significant level, and $*$ denotes $10 \%$ significant level.

\begin{tabular}{lllllll}
\hline & $(1)$ & $(2)$ & $(3)$ & $(4)$ & $(5)$ & $(6)$ \\
\hline LOW RATE $\times$ BGRADE & $0.135^{* *}$ & & $0.264^{* * *}$ & & $0.288^{* * *}$ & \\
& $(0.065)$ & & $(0.078)$ & & $(0.081)$ & \\
LOW RATE $\times$ UNRATED & $0.174^{*}$ & & 0.171 & & $0.335^{* *}$ & \\
& $(0.098)$ & & $(0.117)$ & & $(0.133)$ & \\
LOW RATE & 0.031 & 0.045 & -0.036 & 0.057 & -0.053 & 0.003 \\
& $(0.079)$ & $(0.081)$ & $(0.081)$ & $(0.083)$ & $(0.092)$ & $(0.095)$ \\
BGRADE & $0.124^{*}$ & & 0.080 & & 0.111 & \\
& $(0.070)$ & & $(0.080)$ & & $(0.093)$ & \\
UNRATED & $0.260^{* * *}$ & & $0.253^{* *}$ & & $0.290^{* * *}$ & \\
& $(0.084)$ & & $(0.099)$ & & $(0.108)$ & \\
P DEFAULT & & $0.849^{* * *}$ & & $0.839^{* * *}$ & & $0.869^{* * *}$ \\
& & $(0.142)$ & & $(0.141)$ & & $(0.163)$ \\
LOW RATE $\times$ P DEFAULT & & $0.300^{*}$ & & $0.265^{*}$ & & $0.090^{*}$ \\
& & $(0.177)$ & & $(0.143)$ & & $(0.051)$ \\
Firm Controls & Yes & Yes & Yes & Yes & Yes & Yes \\
Issue Controls & Yes & Yes & Yes & Yes & Yes & Yes \\
Macro Controls & Yes & Yes & Yes & Yes & Yes & Yes \\
Year & Yes & Yes & Yes & Yes & Yes & Yes \\
Quarter & Yes & Yes & Yes & Yes & Yes & Yes \\
Firm FE & Yes & Yes & Yes & Yes & Yes & Yes \\
Observations & 6,923 & 7,708 & 5,618 & 6,277 & 5,263 & 5,173 \\
$R^{2}$ & 0.278 & 0.266 & 0.398 & 0.276 & 0.374 & 0.373 \\
\hline
\end{tabular}




\section{Table 7: ROBUSTNESS CHECKS:}

\section{PROBABILITY OF DEFAULT AFTER LOAN ORIGINATION}

The dependent variable is the probability of default. Each regression includes a set of firm controls, year and firm fixed effects. The firm controls are defined in Appendix 2. After 1year, After 2 years, After 3 years is a categorical variable that takes one if the current year is one, two, or three years after the year of loan origination. The upper and lower panels identify loans originated in times of low and high interest rates, respectively. ${ }^{* * *}$ denotes $1 \%$ significant level, $* *$ denotes $5 \%$ significant level, and $*$ denotes $10 \%$ significant level.

\begin{tabular}{|c|c|c|c|c|}
\hline & \multicolumn{4}{|c|}{ LOW RATES } \\
\hline & $\begin{array}{l}\text { First Loan } \\
(1)\end{array}$ & $\begin{array}{l}\text { Second Loan } \\
(2)\end{array}$ & $\begin{array}{l}\text { Median Loan } \\
\text { (3) }\end{array}$ & $\begin{array}{l}\text { Last Loan } \\
\text { (4) }\end{array}$ \\
\hline After 1 year & $\begin{array}{l}-0.000 \\
(0.002)\end{array}$ & $\begin{array}{l}-0.001 \\
(0.003)\end{array}$ & $\begin{array}{l}-0.005 \\
(0.008)\end{array}$ & $\begin{array}{l}0.002 \\
(0.002)\end{array}$ \\
\hline After 2 years & $\begin{array}{l}-0.002 \\
(0.003)\end{array}$ & $\begin{array}{l}0.001 \\
(0.006)\end{array}$ & $\begin{array}{l}-0.012 \\
(0.014)\end{array}$ & $\begin{array}{l}0.005^{* *} \\
(0.003)\end{array}$ \\
\hline After 3 years & $\begin{array}{l}-0.003 \\
(0.005)\end{array}$ & $\begin{array}{l}0.004 \\
(0.008)\end{array}$ & $\begin{array}{l}-0.010 \\
(0.021)\end{array}$ & $\begin{array}{l}0.009 * * * \\
(0.003)\end{array}$ \\
\hline Firm Controls & Yes & Yes & Yes & Yes \\
\hline Firm FE & Yes & Yes & Yes & Yes \\
\hline$R^{2}$ & 0.060 & 0.121 & 0.231 & 0.156 \\
\hline \multirow[t]{2}{*}{ Observations } & 11,531 & 6,996 & 2,516 & 12,720 \\
\hline & \multicolumn{4}{|c|}{ HIGH RATES } \\
\hline After 1 year & $\begin{array}{l}-0.000 \\
(0.002)\end{array}$ & $\begin{array}{l}-0.001 \\
(0.002)\end{array}$ & $\begin{array}{l}0.005 \\
(0.005)\end{array}$ & $\begin{array}{l}0.004 \\
(0.004)\end{array}$ \\
\hline After 2 years & $\begin{array}{l}-0.003 \\
(0.002)\end{array}$ & $\begin{array}{l}-0.004 \\
(0.003)\end{array}$ & $\begin{array}{l}0.010 \\
(0.008)\end{array}$ & $\begin{array}{l}0.001 \\
(0.002)\end{array}$ \\
\hline After 3 years & $\begin{array}{l}-0.002 \\
(0.003)\end{array}$ & $\begin{array}{l}-0.005 \\
(0.003)\end{array}$ & $\begin{array}{l}0.018 \\
(0.012)\end{array}$ & $\begin{array}{l}-0.004^{*} \\
(0.002)\end{array}$ \\
\hline Firm Controls & Yes & Yes & Yes & Yes \\
\hline Firm FE & Yes & Yes & Yes & Yes \\
\hline$R^{2}$ & 0.087 & 0.112 & 0.168 & 0.188 \\
\hline Observations & 13,291 & 10,176 & 4,271 & 12,247 \\
\hline
\end{tabular}


Table 8: MONETARY POLICY SHOCKS

The dependent variable is L LOAN SPD. ROMER SHOCK and TAYLOR SHOCK take the value of one if the monetary policy is easing and zero otherwise. All other (unreported) controls are defined in Appendix 2. ${ }^{* * *}$ denotes $1 \%$ significant level, ${ }^{* *}$ denotes $5 \%$ significant level, and ${ }^{*}$ denotes $10 \%$ significant level.

\begin{tabular}{lllll}
\hline & $(1)$ & $(2)$ & $(3)$ & $(4)$ \\
\hline ROMER SHOCK P DEFAULT & $-0.245^{*}$ & $-0.321^{*}$ & & \\
ROMER SHOCK & $(0.135)$ & $(0.178)$ & & \\
& -0.023 & $0.033^{* *}$ & & \\
P DEF AULT & $(0.015)$ & $(0.014)$ & & \\
& $1.102^{* * *}$ & $1.108^{* * *}$ & $0.956^{* * *}$ & $1.047^{* * *}$ \\
TAY LOR SHOCK $\times$ P DEFAULT & $(0.192)$ & $(0.191)$ & $(0.086)$ & $(0.149)$ \\
& & & -0.115 & $-0.423^{* *}$ \\
TAY LOR SHOCK & & & $(0.121)$ & $(0.176)$ \\
& & & -0.007 & 0.011 \\
Loan Controls & & & $(0.029)$ & $(0.032)$ \\
Firms Controls & Yes & Yes & Yes & Yes \\
Bank Controls & Yes & Yes & Yes & Yes \\
Macro Controls & Yes & Yes & Yes & Yes \\
Year & Yes & Yes & Yes & Yes \\
Quarter & Yes & Yes & Yes & Yes \\
Bank FE & Yes & Yes & Yes & Yes \\
Bank-Firm FE & Yes & & Yes & Yes \\
$R^{2}$ & & Yes & & 0.286 \\
Observations & 0.542 & 0.301 & 0.527 & 9,861 \\
\hline
\end{tabular}


Table 9: SECOND STAGE REGRESSIONS: LENDING STANDARDS

The dependent variable is L LOAN SPD. EASING $G_{R E S}$ is the generalized residual from a firststage probit regression with dependent variable that takes one if banks are easing their lending standards for approving applications for C\&I loans or credit lines, and zero otherwise. All other variables are defined in Appendix 2. Standard errors are bootstrapped. *** denotes $1 \%$ significant level, $* *$ denotes $5 \%$ significant level, and * denotes $10 \%$ significant level.

\begin{tabular}{|c|c|c|c|c|}
\hline & $(1)$ & $(2)$ & $(3)$ & $(4)$ \\
\hline \multirow[t]{2}{*}{$L O W R A T E$} & $0.073^{* * *}$ & $0.084^{* * *}$ & $0.078^{* * *}$ & $0.100^{* * *}$ \\
\hline & $(0.024)$ & $(0.021)$ & $(0.023)$ & $(0.023)$ \\
\hline \multirow[t]{2}{*}{$P D E F A U L T$} & $1.000^{* * *}$ & $0.705^{* * *}$ & $1.147^{* * *}$ & $1.182^{* * *}$ \\
\hline & $(0.050)$ & $(0.062)$ & $(0.095)$ & $(0.115)$ \\
\hline \multirow{2}{*}{$E A S I N G_{R E S}$} & 0.014 & 0.003 & 0.007 & -0.006 \\
\hline & $(0.009)$ & $(0.008)$ & $(0.015)$ & $(0.013)$ \\
\hline P DEFAULT $\times L O W R A T E$ & & & $\begin{array}{l}-0.193 \\
(0.121)\end{array}$ & $\begin{array}{l}-0.645^{\text {**x }} \\
(0.153)\end{array}$ \\
\hline$E A S I N G_{R E S} \times L O W R A T E$ & & & $\begin{array}{l}0.006 \\
(0.020)\end{array}$ & $\begin{array}{l}0.011 \\
(0.018)\end{array}$ \\
\hline$P D E F A U L T \times E A S I N G_{R E S}$ & 0.034 & 0.102 & $1.178^{* * *}$ & $0.908^{* *}$ \\
\hline$E A S I N G_{R E S} \times L O W R A T E \times P D E F A U L T$ & $(0.087)$ & $(0.080)$ & $\begin{array}{l}(0.334) \\
-1.223^{* * *} \\
(0.354)\end{array}$ & $\begin{array}{c}(0.451) \\
-0.791^{*} \\
(0.479)\end{array}$ \\
\hline Loan Controls & Yes & Yes & Yes & Yes \\
\hline Firm Controls & Yes & Yes & Yes & Yes \\
\hline Bank Controls & Yes & Yes & Yes & Yes \\
\hline Macro Controls & Yes & Yes & Yes & Yes \\
\hline Year & Yes & Yes & Yes & Yes \\
\hline Quarter & Yes & Yes & Yes & Yes \\
\hline Bank FE & Yes & & Yes & \\
\hline Bank-Firm FE & & Yes & & Yes \\
\hline$R^{2}$ & 0.569 & 0.394 & 0.570 & 0.397 \\
\hline Observations & 15,943 & 15,943 & 15,943 & 15,943 \\
\hline
\end{tabular}

Table 10: LOAN SPREADS AND LENDING STANDARDS: MARGINAL EFFECTS

This table reports estimates based on Table 8, column (3). In this particular example, EASING/TIGHT take the values of the $75 \mathrm{th} / 25 \mathrm{th}$ percentile of the distribution of EASING $G_{\text {EES }}$. RISKY and SAFE BORROWERS have probability of default ( $P$ DEFAULT) 0.2 and 0.05, respectively.

\begin{tabular}{llllllll}
\hline & LOW & & & HIGH & & & \\
& EASING & TIGHT & DIFF & EASING & TIGHT \\
$(1)$ & $(2)$ & $(1)-(2)$ & $(3)$ & $\begin{array}{l}\text { DIFF } \\
(4)-(4)\end{array}$ & $\begin{array}{l}\text { DIFF-DIFF } \\
(5)\end{array}$ \\
\hline RISKY BORROWERS & 0.238 & 0.268 & -0.030 & 0.508 & 0.180 & 0.328 & \\
SAFE BORROWERS & 0.129 & 0.123 & 0.006 & 0.133 & 0.044 & 0.089 & \\
DIFF & 0.108 & 0.144 & -0.035 & 0.375 & 0.137 & 0.238 & \\
DIFF-DIFF & & & & & & & -0.274 \\
\hline
\end{tabular}


Table 11: SECOND STAGE REGRESSIONS: RISK TOLERANCE

The dependent variable is L LOAN SPD. RISKTOL $R E S$ is the generalized residual from a first-stage probit regression with dependent variable risk tolerance that takes one if risk tolerance is an important reason for easing lending standards for approving applications for C\&I loans or credit lines, and zero otherwise. All other variables are defined in Appendix 2. Standard errors are bootstrapped. ${ }^{* * *}$ denotes $1 \%$ significant level, ${ }^{* *}$ denotes $5 \%$ significant level, and $*$ denotes $10 \%$ significant level.

\begin{tabular}{|c|c|c|c|c|}
\hline & $(1)$ & $(2)$ & $(3)$ & $(4)$ \\
\hline$L O W R A T E$ & $\begin{array}{l}0.060^{* * *} \\
(0.023)\end{array}$ & $\begin{array}{l}0.084^{* * *} \\
(0.029)\end{array}$ & $\begin{array}{l}0.062^{* *} \\
(0.026)\end{array}$ & $\begin{array}{l}0.105^{* * *} \\
(0.021)\end{array}$ \\
\hline$P D E F A U L T$ & $\begin{array}{l}0.970^{* * *} \\
(0.066)\end{array}$ & $\begin{array}{l}0.672^{* * *} \\
(0.107)\end{array}$ & $\begin{array}{l}1.044^{* * *} \\
(0.091)\end{array}$ & $\begin{array}{l}1.167^{* * *} \\
(0.133)\end{array}$ \\
\hline$R I S K T O L_{R E S}$ & $\begin{array}{l}0.011 \\
(0.010)\end{array}$ & $\begin{array}{l}0.012 \\
(0.010)\end{array}$ & $\begin{array}{l}0.003 \\
(0.020)\end{array}$ & $\begin{array}{l}-0.006 \\
(0.021)\end{array}$ \\
\hline$P D E F A U L T \times L O W$ RATE & & & $\begin{array}{l}-0.092 \\
(0.106)\end{array}$ & $\begin{array}{l}-0.671^{* * *} \\
(0.160)\end{array}$ \\
\hline RISKTOL $L_{R E S} \times L O W R A T E$ & & & $\begin{array}{l}0.010 \\
(0.022)\end{array}$ & $\begin{array}{l}0.023 \\
(0.020)\end{array}$ \\
\hline$P D E F A U L T \times R I S K T O L_{R E S}$ & $\begin{array}{l}-0.189^{* *} \\
(0.076)\end{array}$ & $\begin{array}{l}-0.033 \\
(0.107)\end{array}$ & $\begin{array}{l}1.117^{* * *} \\
(0.394)\end{array}$ & $\begin{array}{l}0.435 \\
(0.542)\end{array}$ \\
\hline$R I S K T O L_{R E S} \times L O W R A T E \times P D E F A U L T$ & & & $\begin{array}{l}-1.395^{* * *} \\
(0.385)\end{array}$ & $\begin{array}{l}-0.445 \\
(0.545)\end{array}$ \\
\hline Loan Controls & Yes & Yes & Yes & Yes \\
\hline Firm Controls & Yes & Yes & Yes & Yes \\
\hline Bank Controls & Yes & Yes & Yes & Yes \\
\hline Macro Controls & Yes & Yes & Yes & Yes \\
\hline Year & Yes & Yes & Yes & Yes \\
\hline Quarter & Yes & Yes & Yes & Yes \\
\hline Bank FE & Yes & & Yes & \\
\hline Bank-Firm FE & & Yes & & Yes \\
\hline$R^{2}$ & 0.586 & 0.412 & 0.586 & 0.414 \\
\hline Observations & 13,488 & 13,488 & 13,488 & 13,488 \\
\hline
\end{tabular}


Table 12: SECOND STAGE: DEMAND FOR LOANS

The dependent variable is L LOAN SPD. DEMAND $R E S$ is the generalized residual from a first-stage probit regression with dependent variable that takes one if a bank considers demand for C\&I loans from large and middle-market firms to be weak over the past three months for reasons other than seasonal variations. All variables are defined in Appendix 2. Standard errors are bootstrapped. ${ }^{* * *}$ denotes $1 \%$ significant level, $* *$ denotes $5 \%$ significant level, and * denotes $10 \%$ significant level.

\begin{tabular}{|c|c|c|c|c|}
\hline & (1) & $(2)$ & $(3)$ & $(4)$ \\
\hline LOW RATE & $0.068^{* *}$ & $0.096^{* * *}$ & $0.075^{* * *}$ & $0.113^{* * *}$ \\
\hline & $(0.031)$ & $(0.023)$ & $(0.022)$ & $(0.027)$ \\
\hline$P D E F A U L T$ & $0.973^{* * *}$ & $0.693^{* * *}$ & $1.033^{* * *}$ & $1.216^{* * *}$ \\
\hline & $(0.057)$ & $(0.113)$ & $(0.069)$ & $(0.145)$ \\
\hline$D E M A N D_{R E S}$ & 0.004 & 0.003 & -0.007 & -0.006 \\
\hline & $(0.006)$ & $(0.007)$ & $(0.008)$ & $(0.009)$ \\
\hline$P D E F A U L T \times L O W R A T E$ & & & $\begin{array}{l}-0.097 \\
(0.082)\end{array}$ & $\begin{array}{l}-0.700^{* * *} \\
(0.152)\end{array}$ \\
\hline$D E M A N D_{R E S} \times L O W R A T E$ & & & $\begin{array}{l}0.025^{* *} \\
(0.011)\end{array}$ & $\begin{array}{l}0.019 \\
(0.014)\end{array}$ \\
\hline$P D E F A U L T \times D E M A N D_{R E S}$ & $\begin{array}{l}0.012 \\
(0.071)\end{array}$ & $\begin{array}{l}0.137 \\
(0.090)\end{array}$ & $\begin{array}{l}0.017 \\
(0.111)\end{array}$ & $\begin{array}{l}0.327^{* *} \\
(0.147)\end{array}$ \\
\hline$D E M A N D_{R E S} \times L O W R A T E \times P D E F A U L T$ & & & $\begin{array}{l}-0.016 \\
(0.153)\end{array}$ & $\begin{array}{l}-0.224 \\
(0.176)\end{array}$ \\
\hline Loan Controls & Yes & Yes & Yes & Yes \\
\hline Firm Controls & Yes & Yes & Yes & Yes \\
\hline Bank Controls & Yes & Yes & Yes & Yes \\
\hline Macro Controls & Yes & Yes & Yes & Yes \\
\hline Year & Yes & Yes & Yes & Yes \\
\hline Quarter & Yes & Yes & Yes & Yes \\
\hline Bank FE & Yes & & Yes & \\
\hline Bank-Firm FE & & Yes & & Yes \\
\hline$R^{2}$ & 0.584 & 0.415 & 0.587 & 0.417 \\
\hline Observations & 14,409 & 14,409 & 14,409 & 14,409 \\
\hline
\end{tabular}




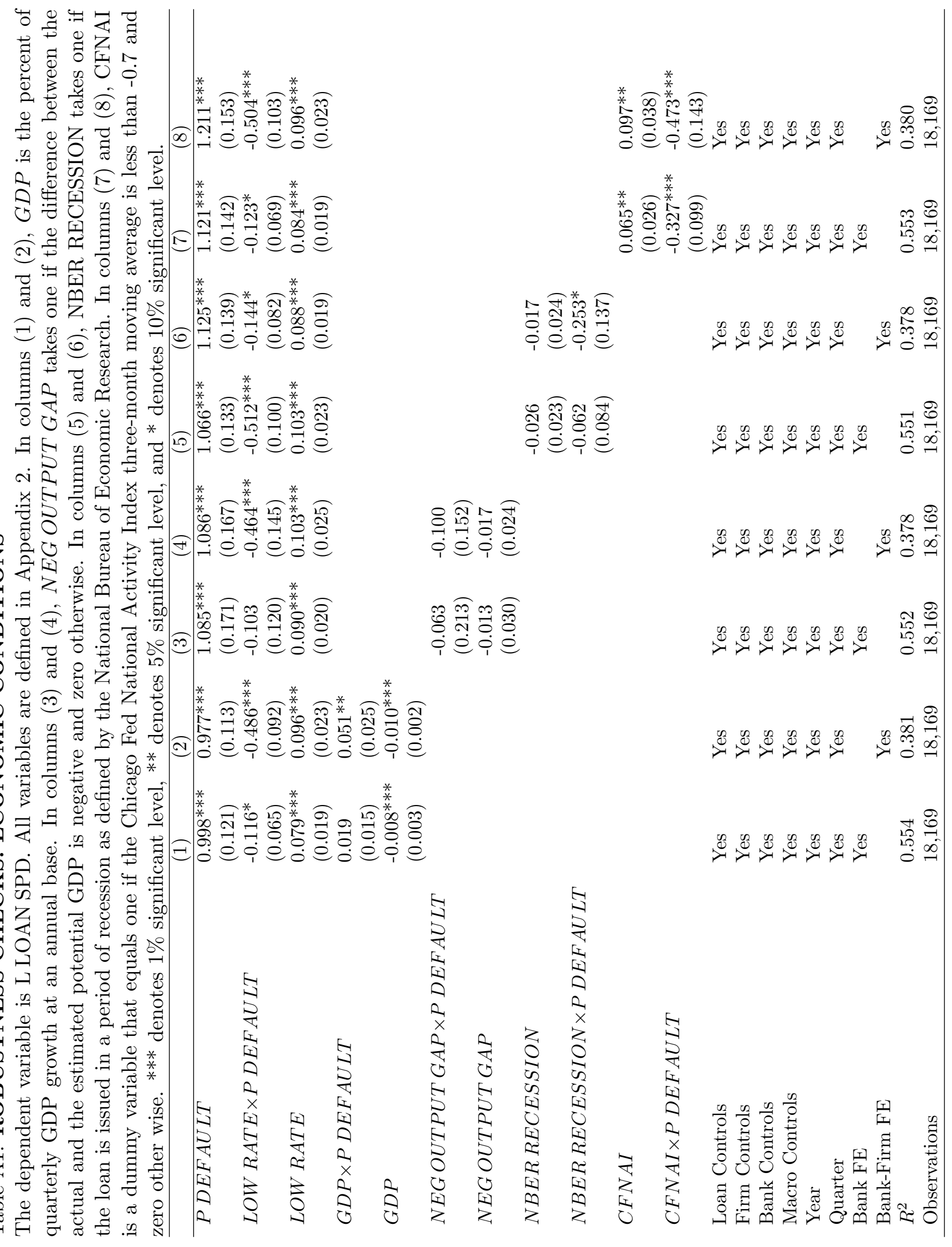


Table A2: ROBUSTNESS CHECKS:

\section{US LENDERS and CANADIAN BORROWERS}

The dependent variable is L LOAN SPD. All variables are defined in Appendix 2. The sample is comprised of Canadian public firms that have borrowed from US lenders. *** denotes $1 \%$ significant level, $* *$ denotes $5 \%$ significant level, and $*$ denotes $10 \%$ significant level.

\begin{tabular}{lllll}
\hline & $(1)$ & $(2)$ & $(3)$ & $(4)$ \\
\hline LOW RATE $\times$ BGRADE & $-0.319^{*}$ & $-0.257^{* *}$ & $-0.319^{*}$ & $-0.406^{*}$ \\
LOW RATE $\times$ UNRATED & $(0.175)$ & $(0.113)$ & $(0.175)$ & $(0.221)$ \\
& -0.026 & -0.136 & -0.026 & -0.142 \\
LOW RATE & $(0.189)$ & $(0.183)$ & $(0.189)$ & $(0.264)$ \\
& -0.029 & -0.021 & -0.029 & -0.086 \\
B GRADE & $(0.370)$ & $(0.373)$ & $(0.370)$ & $(0.166)$ \\
& $1.507^{* * *}$ & $1.064^{* * *}$ & $1.507^{* * *}$ & $0.698^{* * *}$ \\
UNRATED & $(0.111)$ & $(0.104)$ & $(0.111)$ & $(0.164)$ \\
& $1.270^{* * *}$ & $0.689^{* * *}$ & $1.270^{* * *}$ & $0.591^{* * *}$ \\
Loan Controls & $(0.184)$ & $(0.169)$ & $(0.184)$ & $(0.124)$ \\
Firm Controls & No & Yes & No & Yes \\
Bank Controls & No & No & Yes & Yes \\
Macro Controls & Yes & Yes & Yes & Yes \\
Year & Yes & Yes & Yes & Yes \\
Quarter & Yes & Yes & Yes & Yes \\
Bank FE & Yes & Yes & Yes & Yes \\
$R^{2}$ & Yes & Yes & Yes & Yes \\
Observations & 0.389 & 0.539 & 0.389 & 0.771 \\
\hline
\end{tabular}

